Article

\title{
Applying Unconventional Secretion in Ustilago maydis for the Export of Functional Nanobodies
}

\author{
Marius Terfrüchte ${ }^{1,2}$, Michèle Reindl ${ }^{1,2}$, Silke Jankowski ${ }^{1,2}$, Parveen Sarkari ${ }^{3}$, \\ Michael Feldbrügge ${ }^{1,2}$ and Kerstin Schipper ${ }^{1,2, *}$ \\ 1 Institute for Microbiology, Cluster for Excellence on Plant Sciences, Heinrich Heine University Düsseldorf, \\ 40204 Düsseldorf, Germany; marius.terfruechte@hhu.de (M.T.); michele.reindl@hhu.de (M.R.); \\ silke.jankowski@hhu.de (S.J.); feldbrue@hhu.de (M.F.) \\ 2 Bioeconomy Science Center (BioSC), c/o Forschungszentrum Jülich, 52425 Jülich, Germany \\ 3 Department of Biotechnology (DBT), Muthgasse 18, 1190 Vienna, Austria; parveen.sarkari@boku.ac.at \\ * Correspondence: kerstin.schipper@uni-duesseldorf.de; Tel.: +49-211-81-10451; Fax: +49-211-81-15370
}

Academic Editors: Gian-Pietro Di Sansebastiano and Antonio Gaballo

Received: 28 February 2017; Accepted: 24 April 2017; Published: 29 April 2017

\begin{abstract}
Exploiting secretory pathways for production of heterologous proteins is highly advantageous with respect to efficient downstream processing. In eukaryotic systems the vast majority of heterologous proteins for biotechnological application is exported via the canonical endoplasmic reticulum-Golgi pathway. In the endomembrane system target proteins are often glycosylated and may thus be modified with foreign glycan patterns. This can be destructive for their activity or cause immune reactions against therapeutic proteins. Hence, using unconventional secretion for protein expression is an attractive alternative. In the fungal model Ustilago maydis, chitinase Cts1 is secreted via an unconventional pathway connected to cell separation which can be used to co-export heterologous proteins. Here, we apply this mechanism for the production of nanobodies. First, we achieved expression and unconventional secretion of a functional nanobody directed against green fluorescent protein (Gfp). Second, we found that Cts1 binds to chitin and that this feature can be applied to generate a Gfp-trap. Thus, we demonstrated the dual use of Cts1 serving both as export vehicle and as purification tag. Finally, we established and optimized the production of a nanobody against botulinum toxin A and hence describe the first pharmaceutically relevant target exported by Cts1-mediated unconventional secretion.
\end{abstract}

Keywords: Ustilago maydis; unconventional secretion; nanobody; chitinase; botulinum toxin A

\section{Introduction}

Heterologous proteins are preferentially produced in systems in which they are exported into the culture broth, as this simplifies downstream processing and minimizes the production costs substantially [1]. In eukaryotic expression systems secretion is usually achieved via the canonical endoplasmic reticulum (ER)-Golgi pathway. Characteristic signal peptides located at the amino terminus determine the cargo for this route at the beginning of translation and mediate its co-translational uptake into the ER. Folding and protein modifications like $\mathrm{N}$-glycosylation take place during passage of the intermembrane system. Finally, proteins are released to the cell exterior by the fusion of secretory vesicles with the plasma membrane [2,3].

Various well-established expression systems exist, often providing high space-time yields [4,5]. These include for example bacterial systems like Escherichia coli or Bacillus subtilis in which mostly unmodified proteins are produced [6-8]. The yeasts Saccharomyces cerevisiae and Pichia pastoris, 
or filamentous fungi like Aspergilli are established workhorses mainly for generating eukaryotic proteins [9-11]. For production of expensive therapeutic proteins, human or $\mathrm{CHO}$ cell cultures are preferentially used, especially if post-translational modifications are required for protein function $[5,12]$. However, these cultures are more costly, slow growing, and it is elaborate and time-consuming to develop expression lines [4]. Eukaryotic cell-free systems are emerging as an alternative, but are also expensive and only support post-translational modifications in some cases [13]. The choice of an expression system strongly depends on the requirements of the target protein. If a protein can easily be expressed in one of the established systems, this is the preferred production host. However, many desired proteins are still very difficult to produce. Therefore, alternative production strategies are in high demand.

In distinct cases, sending heterologous proteins of interest via the conventional eukaryotic secretion pathway can cause severe problems because they get into contact with the cellular glycosylation machinery. $\mathrm{N}$-glycosylation patterns differ strongly between organisms and therefore, proteins may end up with non-natural modification patterns. This can reduce or destroy protein function or lead to immune reactions if the proteins are used as pharmaceuticals [14]. Thus, proteins which are sensitive to glycosylation cannot be secreted conventionally in a eukaryotic system without changing the native sequence or adapting the glycosylation machinery of the host [14].

Besides the established canonical secretion pathway, other export mechanisms exist that are characterized by the absence of conventional signal peptides. No common scheme can be deduced for these pathways, rather protein export can be mediated by different mechanisms including various membrane vesicles or by direct translocation via pores or transporters [15]. The diverse phenomena of signal peptide independent secretion are summarized using the term unconventional secretion [16]. The biological functions of unconventional secretion are not well understood. However, it seems that in some cases these pathways are essential to avoid ER/Golgi-based modifications and/or to ensure quality control. The mammalian fibroblast growth factor FGF2 can for example be secreted conventionally, but thereby loses its biological activity [17]. Furthermore, $\beta$-galactoside-specific lectins which bind carbohydrates likely avoid conventional secretion to evade potential glycoprotein ligands $[18,19]$.

The fact that ER/Golgi-mediated co- and post-translational modifications are avoided by unconventionally secreted proteins offers new possibilities for applications in biotechnology and medicine $[20,21]$. On this basis, we have established a novel system for protein production in the corn smut fungus Ustilago maydis. Although in its filamentous stage this fungus is the causative agent of corn smut disease, it is safe for biotechnological applications in its non-pathogenic yeast form [22]. Recently, unconventional secretion of the glycoside hydrolase (GH18) family chitinase Cts1 has been demonstrated in $U$. maydis [22-24]. While the exact molecular mechanism of unconventional secretion is still under investigation, the pathway has been evaluated for its use in biotechnology over the last few years [24-27]. Here, heterologous proteins are fused to the N-terminus of Cts1 and are thereby co-exported to the culture supernatant. The bacterial enzyme $\beta$-glucuronidase (Gus) has served as a prime example to validate the feasibility of this approach. While Gus is inactivated by $N$-glycosylation during passage of the conventional secretion pathway of eukaryotes, it can be exported in an active state as a Cts1-fusion protein $[24,28]$. This confirmed that Cts1-mediated unconventional secretion avoids $\mathrm{N}$-glycosylation. Naturally, only low amounts of Cts 1 are released. However, the use of the protease-deficient strains in combination with a very strong promoter significantly enhanced the yields [25]. Two such strains are available: the first carries a deletion of the preproprotease convertase Kexin 2 (Kex2) that activates secreted proteases, and in the second the genes for five major proteases were deleted sequentially. In these adapted strains other targets like single-chain variable fragments could also be secreted in an active state $[21,25]$.

In this study, we further expanded the list of heterologous targets of the Cts1-based expression system and produced nanobodies derived from camelid heavy-chain antibodies [29]. These molecules of about $15 \mathrm{kDa}$ represent the smallest intact antigen-binding fragments known to date [30,31]. Besides 
showing expression of an anti-green fluorescent protein ( $\alpha \mathrm{Gfp})$ nanobody as proof-of-principle, we also for the first time established production of a pharmaceutically relevant protein, namely a nanobody directed against botulinum toxin A (BoNTA).

\section{Results}

\subsection{Expression and Unconventional Secretion of an $\alpha$ Gfp Nanobody}

To evaluate if functional nanobodies can be produced by Cts1-mediated secretion we chose the green fluorescent protein Gfp as a first antigen. A nanobody directed against Gfp $(\alpha \mathrm{GfpNB})$ has been described in an earlier study [32]. For expression, the respective sequence was adapted to the context-dependent dicodon-usage of $U$. maydis (Table S1). This strategy was chosen because in $U$. maydis premature mRNA polyadenylation has been observed for non-optimized genes [33]. In addition, we prefer dicodon optimization, since not only the codon bias but also the neighbouring nucleotides can influence the choice of this codon from the synonymous group [34]. The optimized gene was inserted into the integrative expression vector pRabX2 (Figure 1A) [25]. In this vector, the gene of interest is translationally fused with the $c t s 1$ gene. The encoded fusion protein harbours an $\mathrm{N}$-terminal Histidin (His) tag for purification and an internal HA tag for detection. In addition, the Cts1 carrier can be removed using an internal Tobacco Etch Virus (TEV) protease cleavage site to generate a more natural product with only a small epitope tag (His tag). Gene expression is controlled by the very strong, constitutive, synthetic $\mathrm{P}_{\text {oma }}$ promoter [25]. The pRabX2 derivative encoding the $\alpha \mathrm{GfpNB}-\mathrm{Cts} 1$ fusion was inserted into the ip locus of strain AB33 and the two protease deficient strains AB33kex2 $\triangle$ and $\mathrm{AB} 33 \mathrm{P} 5 \Delta$ by homologous recombination [24,25].

To investigate if the $\alpha \mathrm{GfpNB}-\mathrm{Cts} 1$ fusion protein was produced and secreted, cell extracts and cell-free culture supernatants of the three strains were generated and analysed by Western blot (Figure 1B,C). The 76-kDa protein was present in all cell extracts (Figure 1B). As observed earlier, the Cts1-fusion protein was migrating higher than expected [24]. The amount of extracellular $\alpha \mathrm{GfpNB}$-Cts1 differed depending on the strain background: AB33kex2 $\Delta / \alpha$ GfpNB-Cts1 showed elevated amounts compared to AB33 $\alpha$ GfpNB-Cts1 and AB33P5 $\Delta / \alpha$ GfpNB-Cts1 (Figure 1C). While it is not clear why AB33P5 $\Delta / \alpha$ GfpNB-Cts1 shows a lower protein amount, this was expected for AB33, because this strain still carries all harmful proteases [25]. Although eventually a degradation band was observed which likely accounts to the activity of remaining proteases, AB33kex $2 \Delta / \alpha \mathrm{GfpNB}-\mathrm{Cts} 1$ was used for all further experiments, because it contained the highest amount of full-length protein in the culture supernatant (Figure 1C and Figure S1).

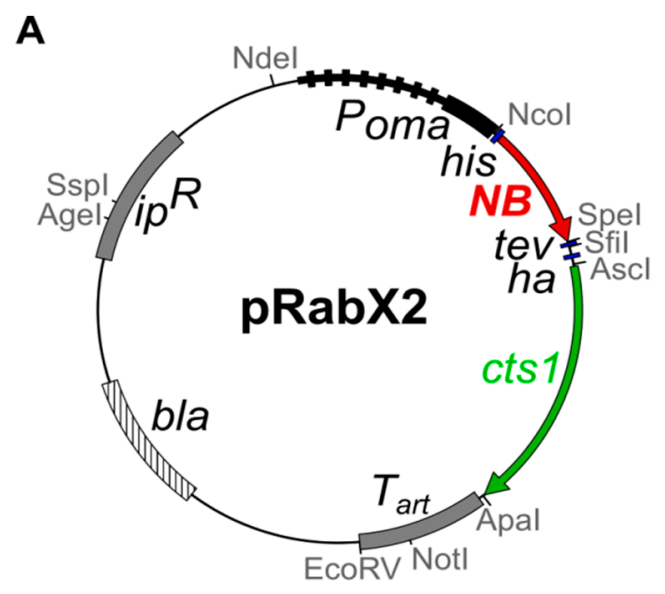

Figure 1. Cont. 
B

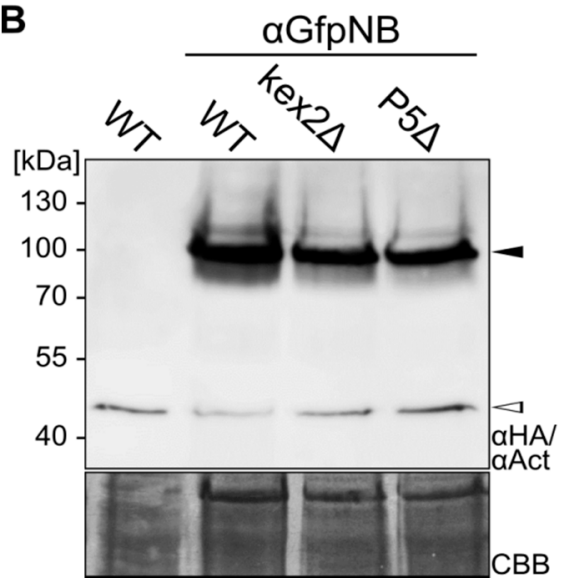

C

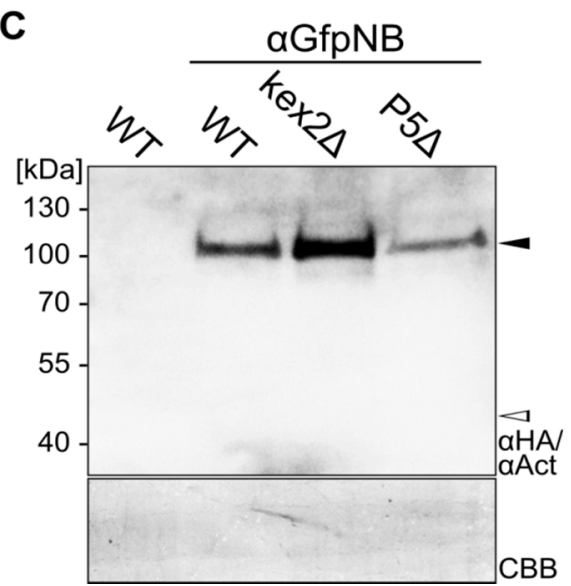

Figure 1. Expression and unconventional secretion of an anti-green fluorescent protein ( $\alpha \mathrm{Gfp}$ ) nanobody in Ustilago maydis. (A) Design of the expression vector for chitinase Cts1-mediated nanobody secretion. Vector backbone $\mathrm{pRabX} 2$ carries the $i p^{r}$ region for targeted homologous recombination. The very strong constitutive promoter $\mathrm{P}_{\text {oma }}$ is used for gene expression. The nanobody is expressed as fusion with a sequence encoding Cts1 and tags for purification and detection. A sequence for a Tobacco Etch Virus (TEV) protease cleavage site is inserted between the two genes. $\mathrm{T}_{\text {art }}$, artificial terminator composed of the ubi1 $3^{\prime} \mathrm{UTR}$ and $\mathrm{T}_{\text {nos }}$ [24]. Black arrowhead indicates the full-length fusion protein, open arrowhead depicts the actin loading control; (B) Expression of the $\alpha \mathrm{GfpNB}$-Cts1 fusion protein in cell extracts $(10 \mu \mathrm{g})$ of indicated AB33 (WT) derivatives assayed by Western blot analysis using an $\alpha \mathrm{HA}$ antibody. Actin-specific antibodies ( $\alpha$ Act) were used in parallel as loading control. The membrane was stained after detection with Coomassie Brilliant Blue (CBB); (C) Detection of unconventionally secreted $\alpha \mathrm{GfpNB}-\mathrm{Cts} 1$ fusion protein in precipitated cell-free culture supernatants (volumetric normalisation) of indicated AB33 (WT) derivatives assayed by Western blot analysis using an $\alpha \mathrm{HA}$ antibody. $\alpha$ Act antibodies were used to exclude cell lysis. The membrane was stained with CBB after detection. Black arrowhead indicates the full-length fusion protein, open arrowhead depicts the actin cell lysis control.

\subsection{Biochemical Characterization of the $\alpha$ Gfp Nanobody}

The functionality of the produced nanobody was tested by its binding activity towards the antigen Gfp in enzyme-linked immunosorbent assays (ELISA). To this end, recombinant His-tagged Gfp $\left(\mathrm{Gfp}^{\mathrm{H}}\right)$ was produced in Escherichia coli using the isopropyl $\beta$-D-1-thiogalactopyranoside (IPTG)-inducible pET system (Novagen) and subsequently enriched by immobilized metal affinity chromatography (IMAC; Figure S2). The purified protein was then coupled to ELISA plates and distinct amounts of AB33 lacking the nanobody (negative control) and AB33kex2 $\Delta / \alpha \mathrm{GfpNB}-\mathrm{Cts} 1$ (expression strain) cell extracts were added. $\alpha \mathrm{HA}$ antibodies were used for detection. Indeed, only wells in which cell extracts of the expression strain containing $\alpha \mathrm{GfpNB}-\mathrm{Cts} 1$ had been added showed signals which were enhanced with the use of elevated protein amounts (Figure 2A). In addition, we performed a positive control experiment using commercial nanobodies (his-tagged Gfp-binding protein, GfpBP, ChromoTek, Planegg, Germany) with an alternative Gfp antigen (Gfp ${ }^{\mathrm{S}}$, Gfp-strep-tag control protein, IBA, Göttingen, Germany; Figure S3). Also, in this experimental setup we detected binding activity for both GfpBP and AB33kex2 $\Delta / \alpha$ GfpNB-Cts1 cell extracts. Signal saturation occurs at $100 \mathrm{ng}$ of purified GfpBP compared to $10-\mu \mathrm{g}$ total cell extract, suggesting that as expected $\alpha \mathrm{GfpNB}$-Cts 1 constitutes about $1 \%$ of the total protein. Altogether, the experiments suggest that the produced nanobody is functional in vitro. The assay was then repeated with purified secreted proteins. Therefore, $\alpha \mathrm{GfpNB}$-Cts1 was enriched from cell-free culture supernatants by IMAC and applied in three different dilutions (Figure 2B). Again, specific signals were obtained only for the proteins purified from the supernatant of the expression strain, confirming secretion of active nanobody. 
A

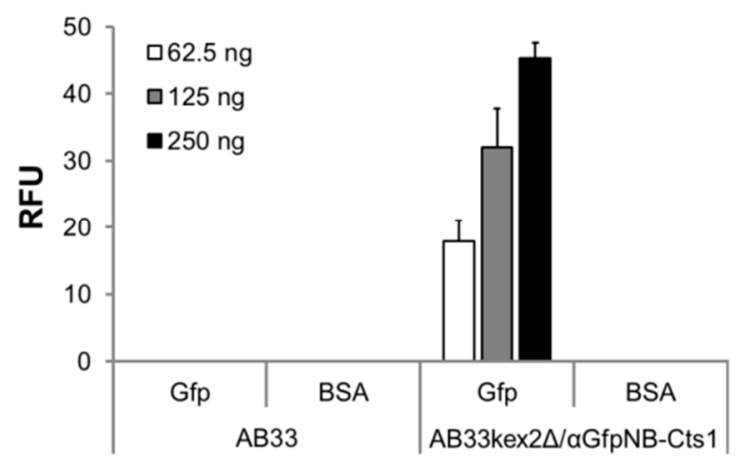

B

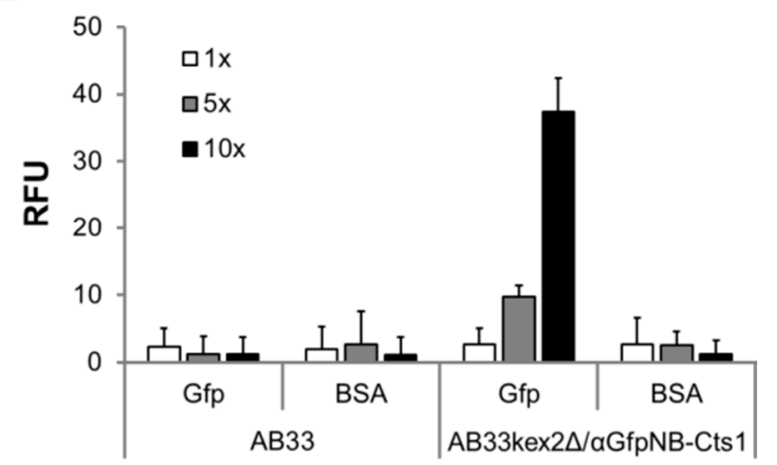

Figure 2. Biochemical characterization of the $\alpha \mathrm{Gfp}$ nanobody. (A) Detection of purified His-tagged green fluorescent protein $\left(\mathrm{Gfp}^{\mathrm{H}}\right)$ in enzyme-linked immunosorbent assays (ELISA) using $10 \mu \mathrm{g}$ of whole cell extracts of strain AB33 (no nanobody) and the Kex2-deficient nanobody expression strain AB33kex2 $\Delta / \alpha$ GfpNB-Cts1; (B) Detection of purified Gfp $^{H}$ in ELISA assays using distinct volumes of immobilized metal affinity chromatography (IMAC)-purified fractions obtained from supernatants of strains AB33 (no nanobody) and AB33kex2 $\Delta / \alpha$ GfpNB-Cts1. ELISA were performed in biological triplicates. BSA, bovine serum albumin; RFU, relative fluorescence units.

As a second proof of nanobody activity we used $10 \mu \mathrm{g}$ of cell extracts derived from the $U$. maydis strain SG200 [35] and its derivative expressing triple Gfp (SG200 Gfp ${ }^{3}$ ) [36] for Western blot analysis. The respective membrane was incubated with $\alpha$ GfpNB-Cts1 purified from cell extracts (Figure 3A) or from cell-free supernatants (Figure 3B) of strain AB33kex $2 \Delta / \alpha \mathrm{GfpNB}-\mathrm{Cts} 1$. Detection with an $\alpha \mathrm{HA}$ antibody revealed signals for triple-Gfp $\left(\mathrm{Gfp}^{3}\right)$ and its degradation products double and single Gfp $\left(\mathrm{Gfp}^{2}, \mathrm{Gfp}\right)$ only in the lane containing cells extracts with the antigen, confirming its functionality in antigen binding.

A

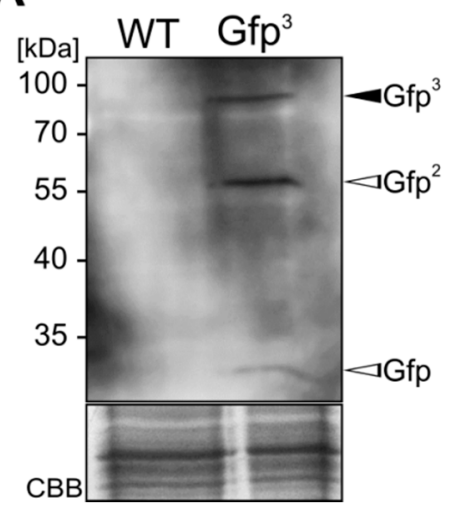

B

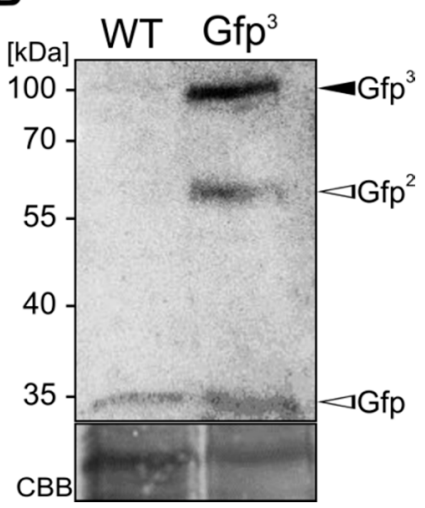

Figure 3. Western blot analyses using an $\alpha \mathrm{Gfp}$ nanobody produced in $U$. maydis. (A) Detection of triple-Gfp $\left(\mathrm{Gfp}^{3}\right)$ by Western blot analysis using the $\alpha \mathrm{GfpNB}-\mathrm{Cts} 1$ fusion protein enriched from cell extracts of strain AB33kex2 $\Delta / \alpha$ GfpNB-Cts1; (B) Detection of Gfp ${ }^{3}$ by Western blot analysis using $\alpha$ GfpNB-Cts1 enriched from culture supernatants of strain AB33kex $2 \Delta / \alpha \mathrm{GfpNB}-\mathrm{Cts} 1$. Besides Gfp ${ }^{3}$ (black arrowheads) its degradation products $\mathrm{Gfp}^{2}$ and single Gfp (open arrowheads) were also detected.

\subsection{Exploiting Intrinsic Chitin-Binding Properties to Establish a Gfp-Trap}

Chitinases of the GH18 family eventually contain chitin-binding motifs (CBM) for interaction with their substrate [37]. The presence of such domain in Cts1 would provide new potential for biotechnological application because it could be applied for purification of the fusion protein. Bioinformatic predictions did not reveal hints for CBM domains in Cts1 [27]. Nevertheless, we 
performed in vitro binding assays to test if Cts1 is able to bind chitin. Therefore, we first produced recombinant His-tagged Cts1 in E. coli. Using again the Novagen pET system (Merck-Millipore, Darmstadt, Germany), large amounts of soluble His-tagged Cts1 $\left(\mathrm{Cts}^{\mathrm{H}}{ }^{\mathrm{H}}\right)$ protein could be enriched by IMAC (Figure 4A). The 56-kDa protein again migrated higher in the Sodium dodecyl sulfate (SDS) gel, but Western blot analyses supported the results [38]. In addition, specific chitinase activity assays confirmed that the recombinant protein was biologically active (Figure 4B) [23].

A
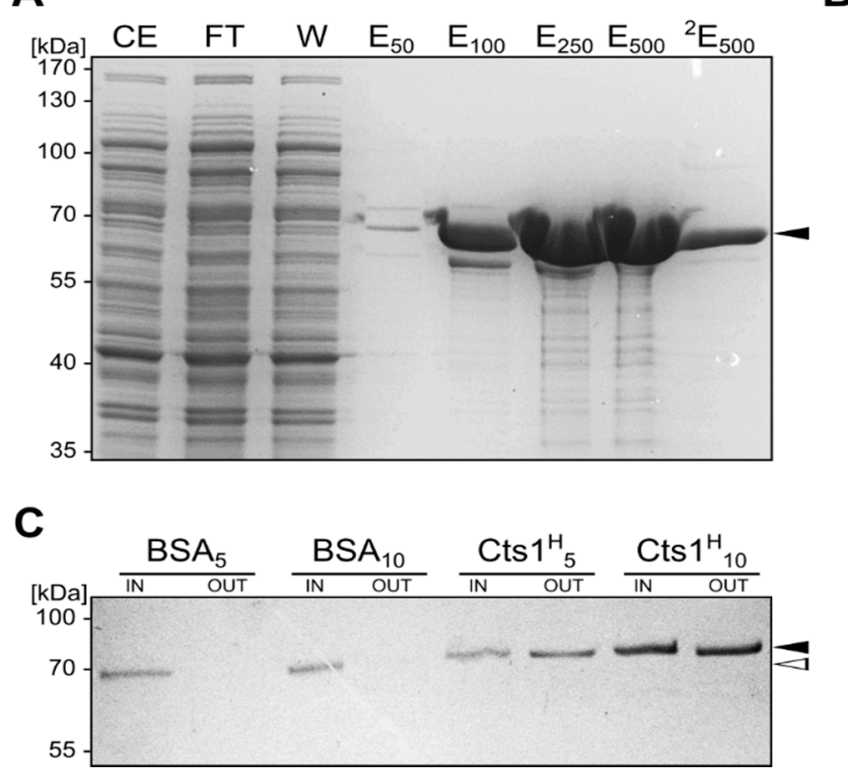

B

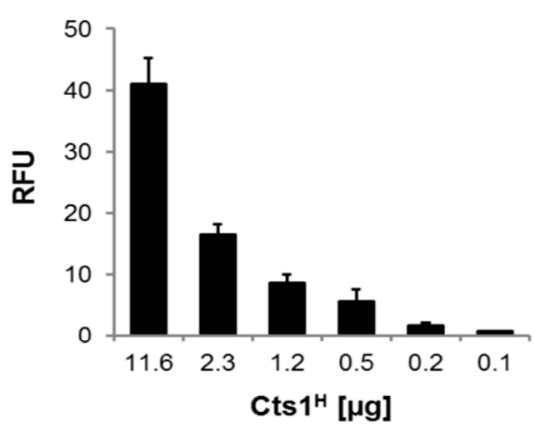

Figure 4. Chitin-binding activity of recombinant Cts1. (A) SDS-PAGE analysis of fractions obtained from IMAC purification of His-tagged Cts1 $\left(\mathrm{Cts}^{\mathrm{H}}\right)$ produced in Escherichia coli. $\mathrm{CE}$, cell extract; FT, flow through; $\mathrm{W}$, wash step; $\mathrm{E}$, elution fractions using different concentrations of imidazole (subscripts). $\mathrm{Cts}^{\mathrm{H}}{ }^{\mathrm{i}}$ is depicted with a black arrowhead; (B) Chitin activity assay with distinct amounts of IMAC purified $\mathrm{Cts} 1 \mathrm{H}$. Activity was determined by monitoring the change in fluorescence using the fluorogenic chitinase substrate 4-methylumbelliferyl $\beta$-D- $N, N^{\prime}, N^{\prime \prime}$-triacetylchitotrioside (4-MUC). RFU, relative fluorescence units; (C) Chitin-binding activity of distinct amounts $(5$ or $10 \mu \mathrm{g})$ of purified Cts $1^{\mathrm{H}}$ (indicated by black arrowhead). Equal amounts of purified BSA (NEB, Ipswich, MA, USA) were used as a negative control (depicted by open arrowhead). Chitin Magnetic Beads were mixed with respective proteins (IN), washed rigorously and bound protein was eluted using Laemmli buffer (OUT).

Next, chitin-binding studies were performed using Chitin Magnetic Beads (New England Biolabs, NEB, Ipswich, MA, USA). In contrast to identical amounts of bovine serum albumin (BSA, NEB) used as a control, Cts1 was able to strongly bind to the beads (Figure $4 \mathrm{C}$ ). This suggests that Cts1 indeed contains a chitin-binding domain that supports the enzyme in its hydrolytic activity towards its substrate. In consequence, a dual use of $\mathrm{Cts} 1$ as a secretion vehicle and purification tag was conceivable.

To apply this finding, we tested if we could generate a Gfp-trap similar to the commercial system (ChromoTek, Planegg-Martinsried, Germany). Therefore, we incubated cell extracts of AB33kex $\Delta / \alpha$ GfpNB-Cts1 and AB33 (negative control) with purified $\mathrm{Gfp}^{\mathrm{H}}$ and incubated the solution with Chitin Resin (NEB, Ipswich, MA, USA). After rigorous washing, proteins were eluted with Laemmli buffer. The $\alpha$ GfpNB-Cts1 fusion protein could be visualized in Coomassie Brilliant Blue (CBB)-stained SDS gels for cell extracts of AB33kex $\Delta / \alpha \mathrm{GfpNB}-\mathrm{Cts} 1$ but not for AB33 purified $\alpha$ GfpNB-Cts1 (Figure 5A,B), showing that chitin affinity is retained in the native protein from $U$. maydis and not hindered by the fusion with the nanobody. In addition, using Western blot analyses, $\mathrm{Gfp}^{\mathrm{H}}$ could be specifically detected in the elution fraction of the Gfp-trap (using cell extracts of AB33kex $\Delta / \alpha$ GfpNB-Cts1; Figure $5 \mathrm{~B}$ ) and not in the control experiment (AB33 cell extracts; 
Figure 5C,D). Chitin binding activity of Cts1 can thus be exploited for pull-down assays as exemplified by the Gfp- $\alpha$ GfpNB-Cts1 interaction. However, it needs to be mentioned that input protein amounts needed to be carefully balanced for this experiment. In more detail, the amount of input protein needs to be titrated before conducting the actual experiment to exclude unspecific binding. In our experimental setup amounts of up to $500 \mathrm{ng} \mathrm{Gfp}^{\mathrm{H}}$ could be applied for the assay without detection of unspecifically bound protein in the elution fraction (Figure S4).

A

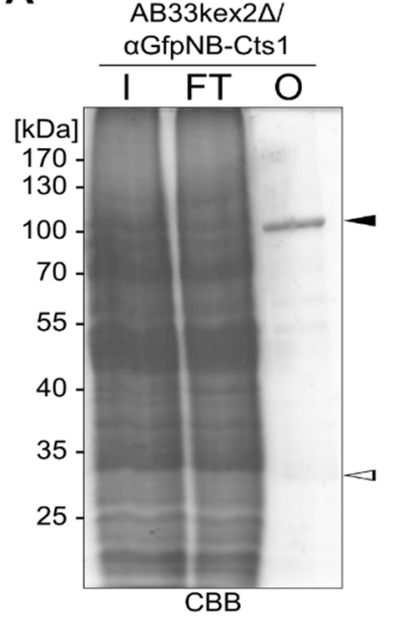

C

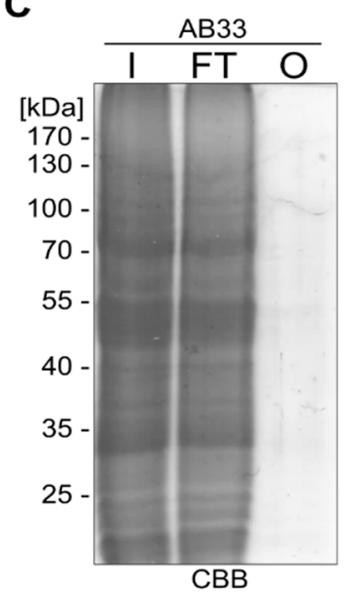

\section{B}

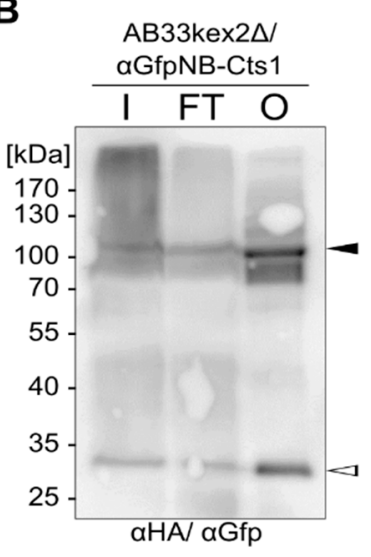

D

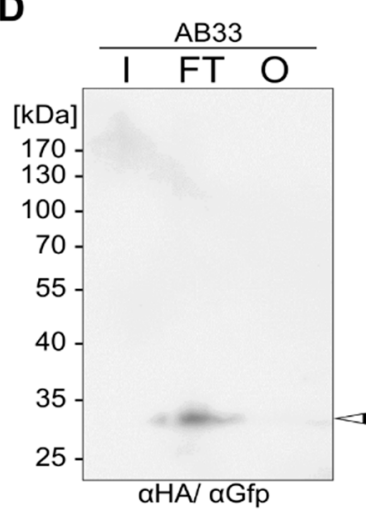

Figure 5. A Gfp-trap based on intrinsic chitin binding activity of Cts1. A total of $1 \mathrm{mg}$ total cell extracts from AB33kex $\Delta / \alpha$ GfpNB-Cts1 or AB33 (negative control) were mixed with $0.5 \mu \mathrm{g}$ purified Gfp ${ }^{\mathrm{H}}(\mathrm{I}$, in). After incubation with chitin resin, proteins were eluted with Laemmli buffer $(\mathrm{O}$, out). FT, flow through after incubation of the resin with the protein suspension. (A) CBB staining visualizes $\alpha \mathrm{GfpNB}-\mathrm{Cts} 1$ that had bound to the column (black arrowhead) and a weak band for co-eluted $\mathrm{Gfp}^{\mathrm{H}}$ (open arrowhead); (B) Western blot analyses of the fractions using $\alpha \mathrm{HA}$ and $\alpha \mathrm{Gfp}$ antibodies confirmed the presence of both $\alpha$ GfpNB-Cts1 fusion protein and Gfp ${ }^{\mathrm{H}}$ (black and open arrowheads, respectively) in the elution fraction; (C) CBB-stained SDS-PAGE and (D) Western blot of control experiments in which equally treated AB33 cell extracts were used. Expected running heights of $\alpha \mathrm{GfpNB}-\mathrm{Cts} 1$ and $\mathrm{Gfp}^{\mathrm{H}}$ are indicated by black and open arrowheads, respectively. No or strongly reduced $\mathrm{Gfp}^{\mathrm{H}}$ elution could be observed. Representative results of four biological replicates are depicted.

\subsection{Expression, Purification and Biochemical Characterization of a Functional Nanobody against Botulinum} Toxin $A$

Unconventional secretion was shown to be suited for export of a functional $\alpha$ Gfp nanobody. Next, we aimed at testing a pharmaceutically relevant nanobody and decided to produce an $\alpha$ BoNTA 
nanobody ( $\alpha$ BoNTANB) that is able to neutralize the very strong botulinum toxin A (BoNTA) from Clostridium botulinum [39]. Expression strain AB33kex $2 \Delta / \alpha$ BoNTANB-Cts1 was generated as described above, using a pRabX2 derivative containing a sequence encoding the $\alpha$ BoNTA nanobody adapted to the context-dependent codon usage of $U$. maydis (Table S1). Comparative Western blot analyses confirmed the presence of the fusion protein $\alpha$ BoNTANB-Cts1 in cell extracts (Figure 6A) and precipitated supernatants (Figure 6B) indicating that the protein is produced and secreted. Of note, the amount of $\alpha$ BoNTANB-Cts1 in culture supernatants was greater compared to $\alpha \mathrm{GfpNB}-\mathrm{Cts} 1$ (Figure 6B). Antigen-binding activity was then assayed using commercial BoNTA-coated ELISA plates (Metabiologics, Inc., Madison, WI, USA). Binding activity could be confirmed both in whole cell extracts and protein enriched from culture supernatants by IMAC (Figure 6C,D). This demonstrates that unconventional secretion can be exploited to generate pharmacologically relevant antibody formats.

A

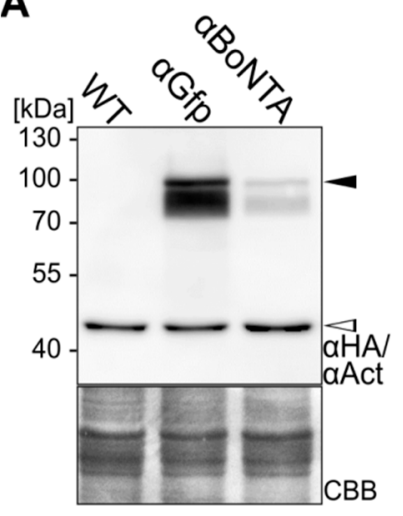

B

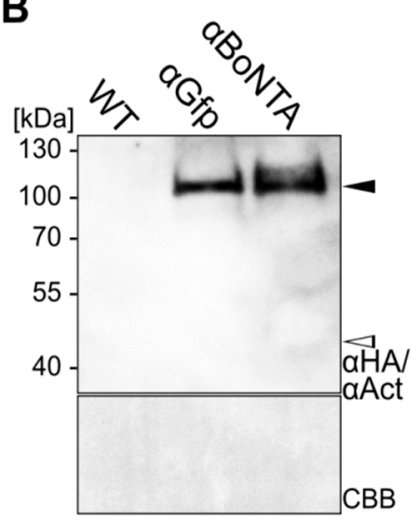

C

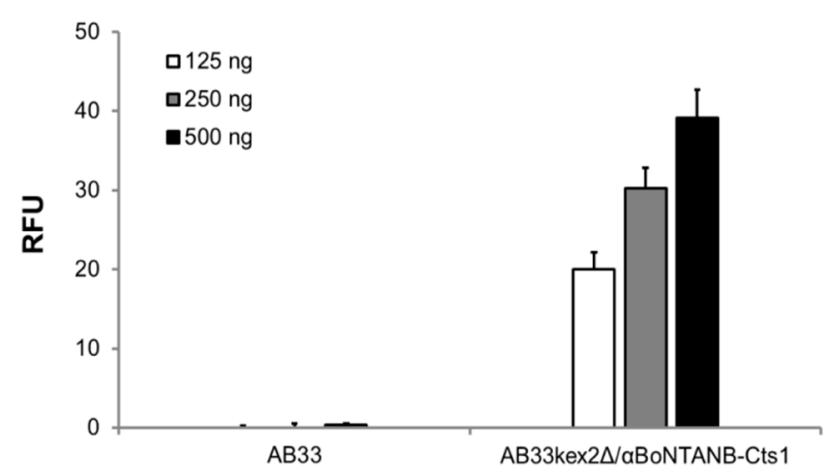

D

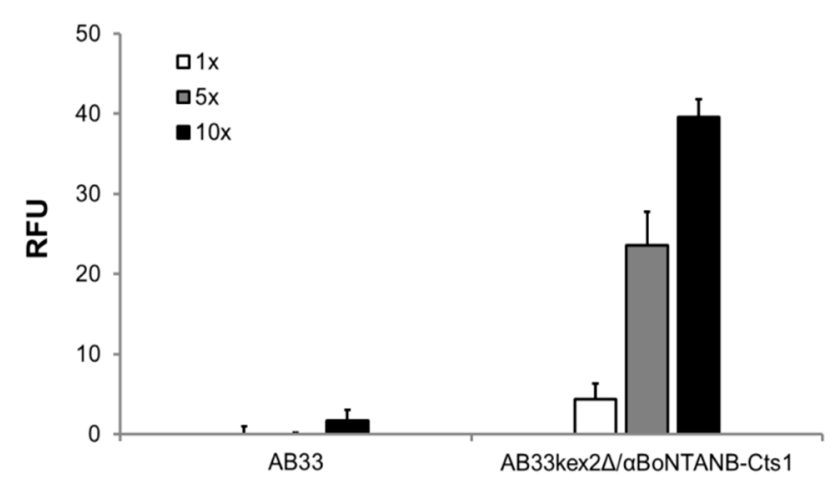

Figure 6. Expression and unconventional secretion of an $\alpha$ BoNTA nanobody. (A,B) Comparative Western blot analysis of whole cell extracts (A) and volumetric precipitated supernatants (B) of the nanobody-Cts1 fusion proteins $\alpha$ GfpNB-Cts1 ( $\alpha \mathrm{Gfp}$ ) and $\alpha$ BoNTANB-Cts 1 ( $\alpha$ BoNTA) produced in strain background $\mathrm{AB} 33 \mathrm{kex} 2 \Delta$. The strain AB33kex2 $\Delta$ (WT) lacking expression constructs was included as negative control. Proteins were detected using an $\alpha \mathrm{HA}$ primary antibody. Actin-specific antibodies $(\alpha$ Act) were used as loading control (open arrowhead). The membranes were stained with CBB after detection. Full length protein bands were obtained for both $\alpha$ BoNTANB-Cts1 (black arrowhead, $74 \mathrm{kDa}$ ) and $\alpha \mathrm{GfpNB}-\mathrm{Cts} 1$ (76 kDa); (C) Distinct amounts of whole cell extracts derived from AB33 and AB33kex $2 \Delta / \alpha$ BoNTANB-Cts1 were analyzed by ELISA using botulinum toxin A (BoNTA) as antigen; (D) Elution fractions from IMAC purifications of AB33 and AB33kex $2 \Delta / \alpha$ BoNTANB-Cts1 supernatant were analyzed in different concentrations $(10 \times, 5 \times, 1 \times)$ by ELISA against BoNTA. ELISA were performed in biological triplicates. RFU, relative fluorescence units. 


\subsection{Optimizing $\alpha$ BoNTA Nanobody Expression}

For initial experiments and biochemical characterization, nanobody expression cultures were harvested at low optical densities (0.5-1). This yielded low levels of secreted protein. To characterize the behavior of cultures grown to higher optical densities, we incubated the expression strain AB33kex $2 \Delta / \alpha$ BoNTANB-Cts 1 for $9 \mathrm{~h}$ in shake flask batch cultures, corresponding to a final optical density of about 3.0. Western blot analyses using volumetric samples taken at different time-points now showed increasingly strong bands for the full length protein (Figure 7A). In line with that, ELISA assays demonstrated increasing signals of the samples harvested over time (Figure 7B). To determine the approximate amount of $\alpha$ BoNTANB-Cts1 secreted in the batch culture, quantitative Western blot analyses were performed using a dilution series of commercial MultiTag ${ }^{\circledR}$ Protein (GenScript, Piscataway, NJ, USA) as an internal standard (Figure S5). According to this quantification, a yield of about $140 \mu \mathrm{g} / \mathrm{L}$ was achieved in the standard batch culture.

A

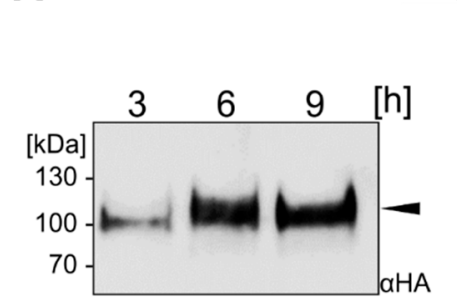

B

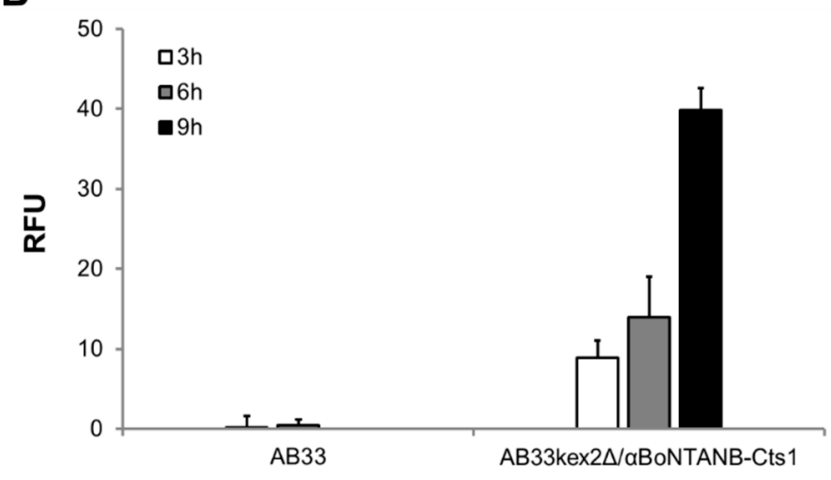

Figure 7. Optimization of $\alpha$ BoNTA nanobody expression. (A) Precipitated cell-free culture supernatants after different times of incubation. The full length fusion protein is depicted with a black arrowhead. Identical volumes of a single culture were analyzed; (B) Supernatant samples harvested at indicated time points were subjected to ELISA against BoNTA (biological triplicates). RFU, relative fluorescence units.

\section{Discussion}

In this study we produced two different heavy-chain antibody-derived nanobodies by Cts1-mediated unconventional secretion in the yeast stage of the fungus $U$. maydis. As a proof-of-principle we first tested a nanobody against Gfp. This nanobody was initially described by Rothbauer and colleagues and was expressed intracellularly as a chromobody in mammalian cells [32]. The group also invented a first versatile nanotrap that was later on developed further and commercialized by the company ChromoTek [40]. Here, we achieved the unconventional secretion of the $\alpha \mathrm{GfpNB}$ in its active form in vitro, suggesting that nanobodies are a suitable target for Cts1-mediated export. In addition, we made the important observation that although Cts1 lacks a classical chitin-binding motif it still sticks to chitin in both its native state or after recombinant expression in E. coli. While chitin binding activity was clearly detected, we did not observe any cleavage of the polysaccharide in in vitro assays [38]. Therefore, this fact can be used to purify Cts1 including its N-terminal protein fusions. In addition, similarly to the commercial Gfp nanotrap, we showed that coupling of $\alpha$ GfpNB-Cts1 to chitin can be applied to pull-down Gfp-now exploiting an intrinsic feature of the carrier Cts1. Importantly, with careful design and appropriate controls this experiment can now be expanded to other applications, for example to perform pull-down experiments with potential Cts1 interaction partners or they may even be applied to identify those. The fact that Cts1 protein produced in E. coli is enzymatically active furthermore confirms that it does not need eukaryotic 
post-translational modifications for function. This is in line with its unconventional secretion during cell separation [27].

In addition, we expressed a camelid-derived nanobody directed against BoNTA [39]. This is the first example of products of pharmaceutical relevance generated by unconventional secretion in $U$. maydis. The functionality of the nanobody in binding its cognate antigen BoNTA in the culture supernatant indicates that the protein folds correctly. However, to finally verify its biological function, studies on BoNTA neutralization would need to be performed in an in vivo model as has been shown in the original study for a mouse or a primary neuron botulism model [38]. To this end, it would be important to also express nanobodies with other neutralizing epitopes such as the $\alpha \mathrm{E}$-Tag in order to expand the clearing potential of the antitoxin and thus enhance the neutralizing effect in vivo [39]. In the future, such nanobodies could deal as an alternative to polyclonal antisera used to date for treating botulism in humans [41,42]. In this therapy it is crucial that the antitoxin both neutralizes toxin function and promotes clearance of toxin from the body which has already been demonstrated for the nanobodies after intravenous injection in a mouse model [39].

Of note, in our study the produced nanobodies carry a small N-terminal His-tag as well as the large C-terminal fusion to Cts1. Tags can potentially interfere with protein function e.g., by blocking the antigen binding site. However, we consider it unlikely that these tags influence the binding activity of the nanobodies because similar $\mathrm{N}$ - and C-terminal extensions have been used successfully in other studies [43-46]. Furthermore, as estimated by the comparison to the positive control GfpBP, the produced $\alpha \mathrm{GfpNB}-\mathrm{Cts} 1$ nanobody fusion shows the expected activity in cell extracts. However, to completely exclude potential steric interferences, we plan to remove the Cts 1 moiety by protease cleavage in the future.

The recombinant expression of nanobodies has been described in diverse studies using for example mammalian cell lines, plants and different microorganisms including Saccharomyces cerevisiae and Aspergillus oryzae with yields in the $\mathrm{mg} / \mathrm{L}$ range [47-49]. Hence, this antibody format is not the most difficult to produce [47]. Therefore, in the next step we will focus on proteinaceous biopharmaceuticals which are more challenging to obtain in microbial systems and try to establish their expression in $U$. maydis. An interesting target could for instance be the plasmodial surface associated protein $\mathrm{P} f \mathrm{RH} 5$ which has been shown to be a highly potent vaccine target against malaria $[50,51]$. In general, proteins of plasmodial origin are difficult to produce in the most commonly available expression systems such as yeasts or bacteria [52-55]. Interestingly, it has been shown that $N$-linked glycosylation impairs functionality of $\mathrm{P} f \mathrm{RH} 5$, making it a perfect target for unconventional secretion in $U$. maydis [56,57].

Still, with about $140 \mu \mathrm{g} / \mathrm{L}$ the yields obtained in our secretory system are too low to be competitive. However, we believe that with different optimization steps we will evolve Cts1-mediated unconventional secretion into a relevant alternative platform for the production of high-value proteins. Even using protease-deficient strains as expression hosts we observe significant degradation of our heterologous target proteins, which limits the yield of active full length protein (unpublished observation) and may even be disruptive during application. Hence, we are currently identifying and eliminating more involved harmful proteases. In addition, medium optimization combined with upscaling to the bioreactor can improve yields to a relevant range. It has been shown before that switching from shake-flask to fermentation can result in yield increase up to 10-fold [58]. Lastly, solving the exact molecular mechanism of unconventional Cts1 secretion will provide novel tools to increase its secretion. Factors essential for its export could for example be overexpressed to boost the pathway. Also, the identification of other proteins following a similar pathway could provide valuable mechanistic insights.

In summary, our study contributes to the rising field of eukaryotic unconventional secretion covered in this special issue and demonstrates its potential for applied research. Our expression system opens up new possibilities for the production of valuable non-glycosylated proteins in an inexpensive eukaryotic system. Target proteins could even originate from prokaryotic sources since these naturally lack glycosylation and thus, their proteins are often sensitive towards this modification. 
In bacteria the signal sequence independent secretion has recently been recognized as a potential alternative way to export heterologous proteins which overburden the conventional Sec or Tat pathways [59,60]. Our study may now provide the starting point to inspire the broader application of other specialized eukaryotic unconventional secretion pathways for applied research in the near future. With the production of several different heterologous proteins like Gus, single-chain variable fragments (scFvs) or nanobodies [24,25] (this study), we have now laid a solid foundation for follow-up studies concentrating on other relevant targets that fulfill the criteria for unconventional secretion and are hard to produce in established systems.

\section{Materials and Methods}

\subsection{Microbial Strains, Culture Conditions and Plasmids}

The E. coli K-12 derivate Top10 (Invitrogen/Life Technologies) was used as a host for molecular cloning. E. coli Rosetta 2 (DE3) pLysS (Merck-Millipore, Darmstadt, Germany; Table 1) was employed for protein expression (see Section 4.5). Bacterial expression cultures were grown at $37{ }^{\circ} \mathrm{C}$ with $200 \mathrm{rpm}$ shaking.

Table 1. E. coli strains used for protein expression.

\begin{tabular}{|c|c|c|c|c|c|}
\hline Strain & $\begin{array}{c}\text { Relevant } \\
\text { Genotype/Resistance }\end{array}$ & $\operatorname{Uma}^{1}$ & Plasmid Transformed & Progenitor & Reference \\
\hline $\begin{array}{l}\text { E. coli Rosetta2 } \\
\text { (DE3) pLysS }\end{array}$ & $\begin{array}{c}F^{-} \text {ompT hsdS }{ }_{B}\left(\mathrm{r}_{\mathrm{B}}^{-} \mathrm{m}_{\mathrm{B}}^{-}\right) \\
\text {gal dcm (DE3) } \\
\text { pLysSRARE2 (CamR) }\end{array}$ & 791 & - & - & $\begin{array}{c}\text { Novagen } \\
\text { (Merck-Millipore) }\end{array}$ \\
\hline $\begin{array}{l}\text { E. coli Rosetta2 } \\
\text { (DE3) pLysS } \\
\text { pET15b_His-Gfp }\end{array}$ & $\begin{array}{c}F^{-} \text {ompT hsdS } S_{B}\left(\mathrm{r}_{\mathrm{B}}-\mathrm{m}_{\mathrm{B}}{ }^{-}\right) \\
\text {gal dcm pLysSRARE2 } \\
\text { (CamR) pET15b_His-Gfp } \\
\text { (AmpR) }\end{array}$ & 1464 & $\begin{array}{c}\text { pET15b_His-Gfp } \\
\text { (pUMa2156) (expression } \\
\text { of a } 6 x \text { His-Gfp fusion } \\
\text { protein) }\end{array}$ & UMa791 & this study \\
\hline $\begin{array}{l}\text { E. coli Rosetta2 } \\
\text { (DE3) pLysS } \\
\text { pET15b_His-Cts1 }\end{array}$ & $\begin{array}{c}F^{-} \text {ompT hsdS }{ }_{B}\left(\mathrm{r}_{\mathrm{B}}^{-} \mathrm{m}_{\mathrm{B}}^{-}\right) \\
\text {gal dcm pLysSRARE2 } \\
\text { (CamR) pET15b_His-Cts1 } \\
\text { (AmpR) }\end{array}$ & 1170 & $\begin{array}{c}\text { pET15b_His-Cts1 } \\
\text { (pUMa1951) (expression } \\
\text { of a } 6 x \text { His-Cts1 fusion } \\
\text { protein) }\end{array}$ & UMa791 & this study \\
\hline
\end{tabular}

U. maydis strains used in this study are listed in Table 2. Cultures were grown in complete medium [61] supplemented with $1 \%(w / v)$ glucose (CM-Glc) at $28^{\circ} \mathrm{C}$ with $200 \mathrm{rpm}$ shaking using baffled flasks. An optical density of $1(\lambda=600 \mathrm{~nm})$ relates to about $1-2 \times 10^{7}$ cells $/ \mathrm{mL}$ [62].

$U$. maydis strains used in this study are listed in Table 2 . All newly generated mutants were obtained by transformation of the progenitor strains with linearized plasmids. For this purpose, integrative expression plasmids derived from pRabX2 [25] (Table 2) were used which contain a region encoding an ip allele that confers resistance to the antibiotic carboxin $\left(i p^{r}\right)$. For integration into the $i p^{s}$ locus by homologous recombination, respective plasmids were linearized within the $i p^{r}$ gene [24]. Subsequently, protoplasts were transformed with the linearized plasmids following published methods [63]. Homologous single or multiple integrations at the ip locus were verified by Southern blot analysis using a 2.1-kb probe obtained with the primer combination oMF502 $\times$ oMF503 (Table 3) and the template pUMa260 [63,64].

To generate plasmid pRabX2 $\mathrm{P}_{\text {oma }}$ His- $\alpha$ GfpNB-TH-Cts1 (pUMa2240) the sequence of the llama-derived $\alpha$ Gfp nanobody [32] was dicodon-optimized (Table S1) and synthetized by the company GeneArt (Thermo Fisher) yielding vector pMA-T Um-anti-Gfp-NB (pUMa2234). The 403-bp coding sequence was next amplified from this template using oRL1577 and oRL1578 introducing terminal NcoI and SpeI sites. The PCR product was hydrolyzed with NcoI and SpeI and inserted into the respective sites of pUMa2137 [25] replacing the scFv gene. 
Table 2. U. maydis strains used in this study.

\begin{tabular}{|c|c|c|c|c|c|c|}
\hline Strains & Relevant Genotype/Resistance & $\mathrm{UMa}^{1}$ & Reference & Plasmid Integrated & Manipulated Locus & Progenitor Strain \\
\hline AB33 & $\begin{array}{c}\text { a2 } P_{\text {nar }} b W 2 b E 1 \\
\text { PhleoR }\end{array}$ & 133 & [65] & - & $b$ & FB2 \\
\hline AB33 $\alpha$ Gfp-Cts1 & $\begin{array}{c}\text { ip } p^{r}\left[P_{\left.\text {omahis:agpf:tev:hacts1:ubi1 } 3^{\prime} U T R\right]} \text { ip }^{s}\right. \\
\text { CbxR }\end{array}$ & 1396 & this study & $\begin{array}{l}\text { pRabX2 PomaHis- } \alpha \text { Gfp-NB-TH-Cts1 } \\
\text { (pUMa2240) }\end{array}$ & $c b x$ & AB33 \\
\hline $\mathrm{AB} 33 \mathrm{kex} 2 \Delta / \alpha \mathrm{Gfp}-\mathrm{Cts} 1$ & 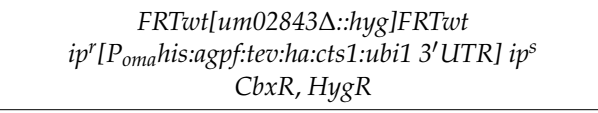 & 1397 & this study & $\begin{array}{l}\text { pRabX2 PomaHis- } \alpha \text { Gfp-NB-TH-Cts1 } \\
\text { (pUMa2240) }\end{array}$ & $c b x$ & UMa803 [25] \\
\hline $\mathrm{AB} 33 \mathrm{P} 5 \Delta / \alpha \mathrm{Gfp}-\mathrm{Cts} 1$ & 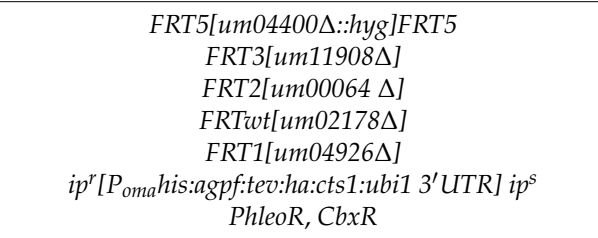 & 1465 & this study & $\begin{array}{l}\text { pRabX2 PomaHis- } \alpha \text { Gfp-NB-TH-Cts1 } \\
\text { (pUMa2240) }\end{array}$ & $c b x$ & UMa1391 [25] \\
\hline SG200 & $\begin{array}{l}a 1: m f a 2, b E 1, b W 2 \\
\text { PhleoR }\end{array}$ & 67 & [35] & - & - & - \\
\hline SG200 Gfp ${ }^{3}$ & $\begin{array}{c}i p^{r}\left[P_{\text {otef }} e g f p: e g f p: e g f p\right] i p^{s} \\
C b x R\end{array}$ & 587 & [36] & - & $c b x$ & SG200 [35] \\
\hline AB33kex $2 \Delta / \alpha$ BoNTA-Cts1 & 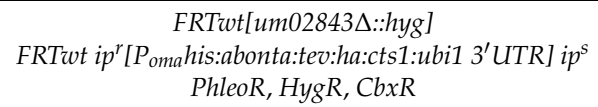 & 1870 & this study & $\begin{array}{l}\text { pRabX2 PomaHis- } \alpha \text { BoNTA-NB-TH-Cts1 } \\
\text { (pUMa2863) }\end{array}$ & $c b x$ & UMa803 [25] \\
\hline
\end{tabular}

${ }^{1}$ Internal strain collection number.

Table 3. DNA oligonucleotides used in this study.

\begin{tabular}{cc}
\hline Designation & Nucleotide Sequence $\mathbf{( 5}^{\prime} \mathbf{- 3}^{\prime \mathbf{})}$ \\
\hline oMF502 & ACGACGTTGTAAAACGACGGCCAG \\
oMF503 & TTCACACAGGAAACAGCTATGACC \\
oRL1085 & oRL1086 \\
oRL1384 & CACCATATGTTTGGACGTCTTAAGCACAGGATGTCTCGCGCTCGACTAGACG \\
oRL1385 & GTGGGATCCTTACTTGAGGCCGTTCTTGACATTGTCCC \\
oRL1577 & GTGGGATCCTTACTTGTACAGCTCGTCCATGCCG \\
oRL1578 & CACCATATGGTGAGCAAGGGCGAGGAGC \\
\hline
\end{tabular}


Dicodon-optimized $\alpha$ BoNTA (Table S2) derived from camelids (ciA-H7, gene bank acc. HQ700708) [38] was synthetized by IDT (Belgium) and delivered in vector pUCIDT_UmciA-H7

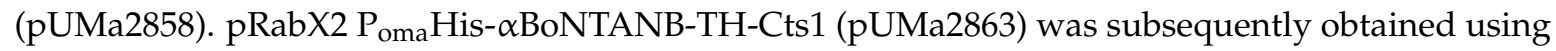
a 371-bp fragment, containing the dicodon-optimized sequence for a His-UmciA-H7 NB ( $\alpha$ BoNTA) fusion protein from pUMa2858, which was cloned into the pUMa2240 expression vector backbone [25], using the restriction endonucleases $\mathrm{NcoI}$ and SpeI.

For generation of pET15b_His-Cts1 (pUMa1951) the cts1 gene was amplified by PCR on the template pUMa1521 [25] using primers oRL1085 and oRL1086. The resulting PCR product (1524 bp) was hydrolyzed with $\mathrm{NdeI}$ and $\mathrm{BamHI}$ and inserted into the respective sites of the pET15b vector (Novagen/Merck-Millipore). For generation of pET15b_His-Gfp (pUMa2156) the $g f p$ gene was amplified from pUMa828 [23] using primers oRL1384 and oRL1385. The 722-bp product was hydrolysed with NdeI and BamHI and inserted into the backbone of pUMa1951 (this study) using the same enzymes, thereby replacing the cts1 open reading frame.

\subsection{Purification of Cts1-Fusion Proteins from $U$. maydis}

Proteins were purified via their N-terminal $10 \times$ Histidin (His) tag from native cell extracts or cell-free culture supernatants using $\mathrm{Ni}^{2+}$-nitrilotriacetic acid (NTA) agarose (Protino ${ }^{\circledR}$, Macherey Nagel, Düren, Germany). The preparation of cell extracts and precipitation of proteins from cell-free culture supernatants have been described before [24,28]. Purification was performed according to the Qiagen Expressionist manual. Therefore, $1 \mathrm{~mL}$ of the matrix was equilibrated with $10 \mathrm{~mL}$ lysis buffer $(50 \mathrm{mM}$ $\mathrm{NaH}_{2} \mathrm{PO}_{4}, 300 \mathrm{mM} \mathrm{NaCl}, 10 \mathrm{mM}$ imidazole, $\mathrm{pH}$ 8.0). A total of $1.5 \mathrm{~mL}$ of native cell extracts was incubated with the equilibrated matrix in a batch procedure $\left(1 \mathrm{~h}, 4^{\circ} \mathrm{C}\right)$. For protein purification from supernatants, a 200 to $500 \mathrm{~mL}$ culture was grown to an $\mathrm{OD}_{600}$ of 0.75 , centrifuged (7000 rpm, $10 \mathrm{~min}$, $4{ }^{\circ} \mathrm{C}$ ) and the supernatant subsequently filtered (MN 615 $1 / 4,150 \mathrm{~mm}$, Macherey Nagel). After addition of one cOmplete ${ }^{\mathrm{TM}}$ EDTA-free Protease Inhibitor Cocktail tablet (Roche, Basel, Switzerland) per $200 \mathrm{~mL}$ supernatant, it was incubated with the equilibrated $\mathrm{Ni}^{2+}$-NTA matrix in a batch procedure $\left(1 \mathrm{~h}, 4^{\circ} \mathrm{C}\right)$. In both cases, after incubation, the matrix was transferred into empty purification columns and washed with $2 \mathrm{~mL}$ of lysis buffer containing different concentrations of imidazole $\left(50 \mathrm{mM} \mathrm{NaH}_{2} \mathrm{PO}_{4}, 300 \mathrm{mM}\right.$ $\mathrm{NaCl}$ supplemented with 20,50 and $100 \mathrm{mM}$ imidazole, $\mathrm{pH}$ 8.0). For elution, the matrix was first treated with $1 \mathrm{~mL}$ lysis buffer containing $250 \mathrm{mM}$ imidazole and then with $2 \mathrm{~mL}$ containing $500 \mathrm{mM}$ imidazole. Samples of all fractions were collected and analyzed by SDS-PAGE. All steps were performed at $4{ }^{\circ} \mathrm{C}$.

\subsection{SDS-PAGE and Western Blot Analysis}

For SDS-PAGE analysis, $10 \%$ acrylamide gels were used. Prior to loading, denaturing $3 \times$ Laemmli sample buffer [66] was added to all samples, followed by boiling at $98{ }^{\circ} \mathrm{C}$ for $10 \mathrm{~min}$ and subsequent centrifugation at $15,000 \times g$ at room temperature for $2 \mathrm{~min}$. Gels were either stained with Coomassie Brilliant Blue (CBB) or blotted onto polyvinylidene difluoride (PVDF) membranes. TBS-T (20 mM Tris- $\mathrm{HCl} \mathrm{pH} 7.6,136 \mathrm{mM} \mathrm{NaCl}, 0.05 \%(v / v)$ Tween-20) supplemented with $3 \%(v / v)$ skimmed milk was applied for blocking. A mouse $\alpha \mathrm{HA}$ antibody (Roche) was used as primary antibody in a dilution of 1:4000. When indicated, a mouse antibody directed against actin ( $\alpha$ Act; MP Biomedicals, Singapore) was in parallel applied in a dilution of 1:1500. A horse $\alpha$ mouse antibody conjugated to horseradish peroxidase (Promega, Madison, WI, USA) dealt as secondary antibody in a concentration of 1:10,000. After incubating the membrane for $1 \mathrm{~min}$ in horseradish peroxidase (HRP)-substrate solution (AceGlow ${ }^{\mathrm{TM}}$, VWR, Erlangen, Germany), chemiluminescence was detected using the LAS4000 (GE Healthcare, Little Chalfont, UK).

CBB staining was used to stain polyacrylamide gels and PVDF membranes. Gels were incubated in Coomassie staining solution (0.05\% Coomassie Brilliant Blue R250, 15\% $(v / v)$ acetic acid, $15 \%(v / v)$ methanol) for $1 \mathrm{~h}$ on an orbital shaker and then washed with $\mathrm{H}_{2} \mathrm{O}$. After incubation for at least $4 \mathrm{~h}$ in destaining solution $(15 \%(v / v)$ acetic acid, $15 \%(v / v)$ methanol), the gel was washed for $1 \mathrm{~h}$ in $\mathrm{H}_{2} \mathrm{O}$. PVDF membranes were incubated for $20 \mathrm{~min}$ in Coomassie staining solution and $20 \mathrm{~min}$ in 
destaining solution with a subsequent $10-\min \mathrm{H}_{2} \mathrm{O}$ washing step after chemiluminescence detection. The membranes were then dried before documentation to reduce background staining.

For quantitative Western blot analysis, commercial purified MultiTag ${ }^{\circledR}$ Protein (LifeTein, Somerset, NJ, USA) was used in defined amounts. Signals were quantified with the Image Studio Lite software (Version 5.2.2, LI-COR, Lincoln, NB, USA).

To analyze the binding activity of the $\alpha \mathrm{GfpNB}$ isolated from $U$. maydis cell extracts, a modified Western blot protocol was applied. First $10 \mu \mathrm{g}$ of native cell extracts from a 3xGfp-expressing strain (UMa587) and of a wildtype negative control (UMa67) were subjected to SDS-PAGE und subsequently blotted on a PVDF membrane. The membrane was then blocked with $3 \%(v / v)$ skimmed milk in PBST (137 mM NaCl, $2.7 \mathrm{mM} \mathrm{KCl}, 10 \mathrm{mM} \mathrm{Na}_{2} \mathrm{HPO}_{4}, 1.8 \mathrm{mM} \mathrm{KH}_{2} \mathrm{PO}_{4}, \mathrm{pH} 7.4,0.05 \%(v / v)$ Tween-20). To specifically detect the Gfp on the PVDF membrane, IMAC-purified $\alpha$ GfpNB-Cts1 fusion protein from UMa1397 cell extracts were used as primary antibodies. Identical volumes of purified protein obtained from UMa1391 were used as negative control. Membranes were incubated overnight on $4{ }^{\circ} \mathrm{C}$ with the purified nanobody mixed with blocking buffer (PBST with $3 \%(v / v)$ skimmed milk). After washing three times with PBST, the standard Western blot detection protocol was followed using $\alpha \mathrm{HA}$ (1:4000, Roche) and horse $\alpha$ mouse-HRP antibodies (1:10,000, Promega).

\subsection{Enzyme-Linked Immunosorbent Assay (ELISA)}

For detection of $\alpha \mathrm{Gfp}$ binding activity, protein-adsorbing 96-well microtiter plates (Nunc MaxiSorp ${ }^{\circledR}$, ThermoFisher Scientific, Waltham, MA, USA) wells were coated with $2 \mu \mathrm{g} \mathrm{Gfp}{ }^{\mathrm{H}}$ (purified from E. coli, see Section 4.5), $2 \mu \mathrm{g}$ BSA (NEB, Ipswich, MA, USA; negative control) or $2 \mu \mathrm{g}$ Gfp $\mathrm{f}^{2}$ (Gfp-strep-tag, IBA, Göttingen, Germany; positive control) in $100 \mathrm{mM}$ bicarbonate coating buffer $\left(100 \mathrm{mM} \mathrm{HCO}_{3}\right)$ at $4{ }^{\circ} \mathrm{C}$ overnight. Blocking was conducted for at least $4 \mathrm{~h}$ at room temperature with $4 \%(w / v)$ skimmed milk in PBS $\left(137 \mathrm{mM} \mathrm{NaCl}, 2.7 \mathrm{mM} \mathrm{KCl}, 10 \mathrm{mM} \mathrm{Na}_{2} \mathrm{HPO}_{4}, 1.8 \mathrm{mM} \mathrm{KH}_{2} \mathrm{PO}_{4}\right.$, $\mathrm{pH}$ 7.4) and subsequently wells were washed three times with PBST (PBS supplemented with $0.05 \%$ $(v / v)$ Tween-20). $\alpha \mathrm{GfpNB}-\mathrm{Cts} 1$ containing samples and appropriate controls were supplemented with skimmed milk in PBS ( $4 \% w / v$ final concentration, f.c.) and then applied either in defined volumes or protein amounts. The plate was incubated with the samples and controls overnight at $4{ }^{\circ} \mathrm{C}$. After $3 \times$ PBS-T washing, a mouse $\alpha$ HA primary antibody 1:4000 diluted in PBS supplemented with skimmed milk ( $4 \% w / v$ f.c.) was added and incubated for $2 \mathrm{~h}$ at room temperature. Alternatively, for the positive control, Gfp-binding protein (ChromoTek) or indicated cell extracts were added and detected with a mouse $\alpha$ His antibody (1:5000, Sigma-Aldrich, Saint Louis, MO, USA). Then, wells were washed again three times with PBS-T and incubated with a horse $\alpha$ mouse-HRP secondary antibody for $1 \mathrm{~h}$ at room temperature (1:5000 in PBS supplemented with skimmed milk ( $4 \% w / v$ f.c.)). After washing again three times with PBST and three times with PBS, $100 \mu \mathrm{L}$ QuantaRed ${ }^{\mathrm{TM}}$ Enhanced Chemifluorescent HRP substrate (ThermoFisher Scientific, Waltham, MA, USA) per well were added. After incubation at room temperature for $1 \mathrm{~h}$, the reaction was stopped with $10 \mu \mathrm{L}$ of stop solution (kit component) and the reactions were transferred into Black $\mu$ Clear $^{\circledR} 96$ Chimney Well plates (flat bottom, Cellstar ${ }^{\circledR}$; Greiner Bio-One, Kremsmünster, Austria). Fluorescence readout was performed at $570 \mathrm{~nm}$ (excitation) and $600 \mathrm{~nm}$ (emission) using an Infinite M200 plate reader (Tecan, Männedorf, Switzerland).

To test antigen binding of $\alpha$ BoNTANB-Cts1, BoNTA-coated 96-well microtiter plates (Metabiologics Inc., Madison, WI, USA) were used. The wells were blocked with $4 \%(w / v)$ skimmed milk in PBS for at least $4 \mathrm{~h}$ at room temperature and after $3 \times$ PBS-T washing, $\alpha$ BoNTANB-Cts1 containing cell extracts, supernatants or purified $\alpha$ BoNTANB-Cts 1 from cell extracts or supernatants as well as the corresponding negative controls were applied to the wells either in defined volumes or protein concentrations. Subsequently, the protocol described above was followed.

\subsection{E. coli Expression and Purification Gfp and Chitinase}

Heterologous expression of $\mathrm{Gfp}^{\mathrm{H}}$ and $\mathrm{Cts}^{\mathrm{H}}$ (both proteins tagged with a $6 \times$ His tag at the N-terminus) was performed in E. coli Rosetta (DE3) pLysS using plasmids pET15b_His-Gfp (pUMa2156) 
and pET15b_His-Cts1 (pUMa1951), respectively. For expression of $\mathrm{Cts}^{\mathrm{H}}$ and $\mathrm{Gfp}^{\mathrm{H}}$ transformants of E. coli Rosetta (DE3), pLysS harboring the respective expression plasmid were grown at $37^{\circ} \mathrm{C}$ to an $\mathrm{OD}_{600}$ of 0.6. Then, expression was induced with $0.5 \mathrm{mM} \mathrm{IPTG}$ and the culture was incubated for further $3 \mathrm{~h}$ until harvest. The cell pellet was resuspended in lysis buffer $\left(50 \mathrm{mM} \mathrm{NaH} \mathrm{PO}_{4}\right.$, $300 \mathrm{mM} \mathrm{NaCl}, 10 \mathrm{mM}$ imidazole, supplemented with cOmplete ${ }^{\circledR}$ EDTA-free Protease Inhibitor Cocktail (1 tablet/100 mL; Roche)). Cells were disrupted using an ultrasonic sonotrode (5 mm microtip (Heinemann, Portsmouth, NH, USA)) attached to the Cell Disruptor B15 device (Branson; stage 4, $3 \times 30$ s pulse, 3 repetitions). Cell extracts were subsequently centrifuged at $5000 \times g$ for $10 \mathrm{~min}$ $\left(4{ }^{\circ} \mathrm{C}\right)$ and subjected to purification. Soluble proteins were purified at $4{ }^{\circ} \mathrm{C}$ with immobilized metal affinity chromatography (IMAC) following standard protocols (The QIAexpressionist, Qiagen, Hilden, Germany). To enhance binding, the protein extracts were batch incubated with $\mathrm{Ni}^{2+}$-NTA matrix for $1 \mathrm{~h}$ at $4{ }^{\circ} \mathrm{C}$ with gentle agitation. After collecting the flow through, the matrix was washed with 10 and $20 \mathrm{mM}$ imidazole. Elution occurred stepwise using up to $250 \mathrm{mM}$ imidazole $\left(\mathrm{Gfp}^{\mathrm{H}}\right)$ or $500 \mathrm{mM}$ imidazole $\left(\mathrm{Cts}^{\mathrm{H}}\right)$ in lysis buffer. Subsequently, a buffer exchange was conducted with different elution fractions enriched in $\mathrm{Cts}^{\mathrm{H}}$ or Gfp ${ }^{\mathrm{H}}$ using PD10-columns (GE Healthcare) following the manufacturer's protocol. Purified target protein was then eluted in potassium-hepes-magnesium chloride (KHM) buffer (Cts1 ${ }^{\mathrm{H}}$; $110 \mathrm{mM}$ potassium acetate, $20 \mathrm{mM}$ HEPES, $2 \mathrm{mM} \mathrm{MgCl} 2$ ) and supplemented with $10 \%(v / v)$ glycerol or PBS/glycerol $\left(\mathrm{Gfp}^{\mathrm{H}}\right.$; PBS supplemented with $10 \%(v / v)$ glycerol). Protein concentration was determined using Bio-Rad Bradford Protein Assay (Bio-Rad Laboratories, Hercules, CA, USA; Bradford, 1976). All obtained fractions were analyzed using SDS-PAGE and Western blot analysis. Eluted proteins were stored at $-20^{\circ} \mathrm{C}$ until further use.

\subsection{Chitin Binding Assay}

Chitin binding activity of $\mathrm{Cts} 1{ }^{\mathrm{H}}$ purified from $E$. coli was assayed using chitin-coated magnetic beads (NEB, Ipswich, MA, USA). First, $50 \mu \mathrm{L}$ magnetic bead slurry was washed twice with $500 \mu \mathrm{L}$ chitin binding buffer (CBD, $500 \mathrm{mM} \mathrm{NaCl}, 20 \mathrm{mM}$ Tris-HCl, 1 mM EDTA, 0.1\% (v/v) Tween-20, pH 8.0). The supernatant was discarded. Next, 5 or $10 \mu \mathrm{g}$ purified $\mathrm{Cts}^{\mathrm{H}}{ }^{\mathrm{H}}$ and commercial purified bovine serum albumin (BSA, NEB, Ipswich, MA, USA), respectively, were incubated in a total volume of $500 \mu \mathrm{L}$ CBD buffer with the washed beads for $1 \mathrm{~h}$ at $4{ }^{\circ} \mathrm{C}$ with agitation. Subsequently, the supernatant was discarded and unbound protein was washed off with $500 \mu \mathrm{L}$ CBD buffer for $30 \mathrm{~min}$ with agitation $\left(4{ }^{\circ} \mathrm{C}\right)$. The step was repeated once. Finally, three short washing steps with $500 \mu \mathrm{L}$ CBD buffer without incubation but with multiple inversions of the tube were conducted. To elute bound protein, $15 \mu \mathrm{L}$ $1 \times$ Laemmli buffer were added to the beads and incubated for $5 \mathrm{~min}$ at room temperature. The supernatant was transferred to a new tube and boiled for $5 \mathrm{~min}$ prior to SDS-PAGE analysis.

\subsection{Chitinase Activity Assay}

Chitinolytic activity of IMAC purified $\mathrm{Cts}^{\mathrm{H}}{ }^{\mathrm{H}}$ was analyzed using the fluorogenic chitinase substrate 4-Methylumbelliferyl- $\beta-\mathrm{D}-N, N^{\prime}, N^{\prime \prime}$-triacetylchitotriosid (4-MUC; Sigma-Aldrich, Taufkirchen, Germany). To this end, a $200 \mathrm{ng} / \mathrm{mL}$ 4-MUC stock solution was prepared in KHM buffer (110 $\mathrm{mM} \mathrm{CH}_{3} \mathrm{CO}_{2} \mathrm{~K}, 20 \mathrm{mM}$ HEPES ( $\left.\mathrm{pH} 7.3\right), 2 \mathrm{~nm} \mathrm{MgCl}_{2}$ ). A quantity of $70 \mu \mathrm{L}$ of the substrate solution was mixed with $30 \mu \mathrm{L}$ sample solution $\left(11.6,2.3,1.2,0.5,0.2,0.1 \mu \mathrm{g}\right.$ in $\mathrm{H}_{2} \mathrm{O}_{\text {bid }}$ ) in Black $\mu$ Clear $^{\circledR} 96$ Chimney Well plates (flat bottom, Cellstar ${ }^{\circledR}$; Greiner Bio-One). The plate was immediately covered with Parafilm ${ }^{\circledR} \mathrm{M}$ (Brand ${ }^{\circledR}$, Wertheim, Germany), protected from light and incubated at $37^{\circ} \mathrm{C}$ for one hour. The enzymatic reaction was stopped by adding $200 \mu \mathrm{L} 1 \mathrm{M} \mathrm{Na}_{2} \mathrm{CO}_{3}$ and fluorescence measurements were performed at $360 \mathrm{~nm}$ (excitation) and $450 \mathrm{~nm}$ (emission) in an Infinite ${ }^{\circledR} 200$ PRO plate reader (Tecan Group AG, Männedorf, Switzerland). Fluorescence of each sample was determined in technical triplicates. 


\subsection{Gfp Pull-Down with Chitin-Bound Cts1}

$\alpha \mathrm{GfpNB}-\mathrm{Cts} 1$ full-length protein was enriched from native cell extracts of AB33kex $2 \Delta / \alpha \mathrm{GfpNB}-\mathrm{Cts} 1 \mathrm{using}$ chitin resin. For the cell extraction cells of AB33kex $2 \Delta / \alpha \mathrm{GfpNB}-\mathrm{Cts} 1$ or AB33 (negative control without $\alpha \mathrm{GfpNB}-\mathrm{Cts} 1$ ) were harvested at their logarithmical growth phase $\left(\mathrm{OD}_{600}=0.7\right)$. Pellets were resuspended in $2 \mathrm{~mL}$ native extraction buffer (chitin binding buffer; $500 \mathrm{mM} \mathrm{NaCl}, 50 \mathrm{mM}$ Tris- $\mathrm{HCl}$ (pH 8), $0.5 \mathrm{mM}$ EDTA, 0.1\% ( $v / v$ ) Tween-20, $1 \mathrm{mM}$ PMSF, $2.5 \mathrm{mM}$ benzamidine, and $2 \times$ cOmplete $^{\mathrm{TM}}$ EDTA-free Protease Inhibitor Cocktail (Roche)) and frozen in liquid nitrogen. Cell extraction was performed using a pebble mill (Retsch; $5 \mathrm{~min}$ at $30 \mathrm{~Hz}$ ). After centrifugation $\left(6000 \times \mathrm{g}\right.$ for $30 \mathrm{~min}$ at $\left.4{ }^{\circ} \mathrm{C}\right)$ the protein concentration was determined by Bradford Protein Assay (Bio-Rad; Bradford, 1976). A total of $1 \mathrm{mg}$ of total protein was supplemented with $100 \mu \mathrm{L}$ of Chitin Resin (NEB, Ipswich, MA, USA, S6651L) and $0.5 \mu \mathrm{g}$ of Gfp ${ }^{\mathrm{H}}$ (expressed and IMAC purified from E. coli (see Section 4.5)). Alternatively, for the titration of $\mathrm{Gfp}^{\mathrm{H}}$ loading, the experiment was performed without cell extracts using the indicated amounts of purified $\mathrm{Gfp}^{\mathrm{H}}$. The suspension was incubated for $3 \mathrm{~h}$ at $4{ }^{\circ} \mathrm{C}$ with agitation. Centrifugation chromatography columns (Pierce ${ }^{\circledR}$ Spin Cups, Thermo Scientific, Waltham, MA, USA) were loaded with the suspension. After collection of the flow through fraction $\left(0.9 \times g\right.$ for $1 \mathrm{~min}$ at $\left.4{ }^{\circ} \mathrm{C}\right)$ the resin was subjected to four washing steps with each $400 \mu \mathrm{L}$ chitin binding buffer. All collected fractions were treated with trichloroacetic acid (TCA) to precipitate contained proteins. Finally, $20 \mu \mathrm{L}$ of $3 \times$ Laemmli buffer $(150 \mathrm{mM}$ Tris- $\mathrm{HCl}$ (pH 6.8), $6 \%(v / v)$ SDS, 30\% (v/v) glycerol, $15 \%(w / v) \beta$-mercaptoethanol, $0.003 \%(w / v)$ bromophenol blue) were added to the column and incubated at $95^{\circ} \mathrm{C}$ for 5 min to elute $\alpha$ GfpNB-Cts $1(0.9 \times g$ for $2 \mathrm{~min})$. To analyze enrichment of $\alpha \mathrm{GfpNB}-\mathrm{Cts} 1$ and $\mathrm{Gfp}^{\mathrm{H}}$, pull-down precipitated fractions were subjected to SDS-PAGE and Western blot analysis.

\section{Conclusions}

The constantly rising request for recombinant proteins in both fundamental and applied research calls for the establishment of alternative expression systems that complement existing platforms. High-value proteins are of special interest for the field of red biotechnology where these products are applied in medicine and diagnostics. In the present study we used the previously described Cts1-mediated unconventional secretion pathway in $U$. maydis to co-export functional nanobodies directed against botulinum toxin A. This is the first example for a pharmaceutically relevant protein produced via this pathway in U. maydis. Currently, we are optimizing the expression system on different levels in order to obtain higher yields and less degradation of the exported proteins in the culture broth. Hence, in the future the optimized system will provide a valuable tool to produce otherwise difficult-to-express proteinaceous biopharmaceuticals in an easy to handle and innocuous eukaryotic host.

Supplementary Materials: Supplementary materials can be found at www.mdpi.com/1422-0067/18/5/937/s1.

Acknowledgments: We thank all lab members for valuable discussion as well as Bettina Axler for excellent technical support of the project. Florian Finkernagel, Miroslav Vraneš and Jörg Kämper provided a bioinformatics tool for automated generation of $U$. maydis codon-optimized sequences. Michael Feldbrügge was supported by CEPLAS DFG-EXC 1028. Marius Terfrüchte and Parveen Sarkari received scholarships from the Ministry of Innovation, Science and Research of North Rhine-Westphalia and Heinrich Heine University Düsseldorf within the CLIB-Graduate Cluster Industrial Biotechnology. Michael Feldbrügge, Kerstin Schipper and Michèle Reindl receive funding from the SFB1208 Membrane Dynamics and Identity. The scientific activities of the Bioeconomy Science Center were supported financially by the Ministry of Innovation, Science and Research within the framework of the NRW Strategieprojekt BioSC (No. 313/323-400-002 13).

Author Contributions: Marius Terfrüchte, Michèle Reindl, Silke Jankowski, and Parveen Sarkari performed the experiments; Marius Terfrüchte, Michael Feldbrügge and Kerstin Schipper conceived and designed the experiments; Marius Terfrüchte, Michèle Reindl, Parveen Sarkari analyzed the data; Kerstin Schipper wrote the manuscript with input of all co-authors.

Conflicts of Interest: The authors declare no conflict of interest. 


\section{Abbreviations}

$\begin{array}{ll}\text { ER } & \text { Endoplasmic reticulum } \\ \text { NB } & \text { Nanobody; BoNTA, botulinum toxin A } \\ \alpha & \text { Anti } \\ \text { CBB } & \text { Coomassie brilliant blue } \\ \text { Gfp } & \text { Green fluorescent protein } \\ \text { IMAC } & \text { Immobilized metal affinity chromatography }\end{array}$

\section{References}

1. Berlec, A.; Strukelj, B. Current state and recent advances in biopharmaceutical production in Escherichia coli, yeasts and mammalian cells. J. Ind. Microbiol. Biotechnol. 2013, 40, 257-274. [CrossRef] [PubMed]

2. Walter, P.; Lingappa, V.R. Mechanism of protein translocation across the endoplasmic reticulum membrane. Annu. Rev. Cell Biol. 1986, 2, 499-516. [CrossRef] [PubMed]

3. Viotti, C. ER to golgi-dependent protein secretion: The conventional pathway. Methods Mol. Biol. 2016, 1459, 3-29. [PubMed]

4. Demain, A.L.; Vaishnav, P. Production of recombinant proteins by microbes and higher organisms. Biotechnol. Adv. 2009, 27, 297-306. [CrossRef] [PubMed]

5. Wells, E.; Robinson, A.S. Cellular engineering for therapeutic protein production: Product quality, host modification, and process improvement. Biotechnol. J. 2017, 12. [CrossRef] [PubMed]

6. Jia, B.; Jeon, C.O. High-throughput recombinant protein expression in Escherichia coli: Current status and future perspectives. Open Biol. 2016, 6, 160196. [CrossRef] [PubMed]

7. Pohl, S.; Harwood, C.R. Heterologous protein secretion by bacillus species from the cradle to the grave. Adv. Appl. Microbiol. 2010, 73, 1-25. [PubMed]

8. Terpe, K. Overview of bacterial expression systems for heterologous protein production: From molecular and biochemical fundamentals to commercial systems. Appl. Microbiol. Biotechnol. 2006, 72, 211-222. [CrossRef] [PubMed]

9. Idiris, A.; Tohda, H.; Kumagai, H.; Takegawa, K. Engineering of protein secretion in yeast: Strategies and impact on protein production. Appl. Microbiol. Biotechnol. 2010, 86, 403-417. [CrossRef] [PubMed]

10. Ahmad, M.; Hirz, M.; Pichler, H.; Schwab, H. Protein expression in Pichia pastoris: Recent achievements and perspectives for heterologous protein production. Appl. Microbiol. Biotechnol. 2014, 98, 5301-5317. [CrossRef] [PubMed]

11. Nevalainen, H.; Peterson, R. Making recombinant proteins in filamentous fungi-Are we expecting too much? Front. Microbiol. 2014, 5, 75. [PubMed]

12. Zhu, J. Mammalian cell protein expression for biopharmaceutical production. Biotechnol. Adv. 2012, 30, 1158-1170. [CrossRef] [PubMed]

13. Zemella, A.; Thoring, L.; Hoffmeister, C.; Kubick, S. Cell-free protein synthesis: Pros and cons of prokaryotic and eukaryotic systems. Chembiochem 2015, 16, 2420-2431. [CrossRef] [PubMed]

14. Gerngross, T.U. Advances in the production of human therapeutic proteins in yeasts and filamentous fungi. Nat. Biotechnol. 2004, 22, 1409-1414. [CrossRef] [PubMed]

15. Steringer, J.P.; Müller, H.M.; Nickel, W. Unconventional secretion of fibroblast growth factor 2-A novel type of protein translocation across membranes? J. Mol. Biol. 2015, 427, 1202-1210. [CrossRef] [PubMed]

16. Rabouille, C.; Malhotra, V.; Nickel, W. Diversity in unconventional protein secretion. J. Cell Sci. 2012, 125, 5251-5255. [CrossRef] [PubMed]

17. Wegehingel, S.; Zehe, C.; Nickel, W. Rerouting of fibroblast growth factor 2 to the classical secretory pathway results in post-translational modifications that block binding to heparan sulfate proteoglycans. FEBS Lett. 2008, 582, 2387-2392. [CrossRef] [PubMed]

18. Hughes, R.C. Secretion of the galectin family of mammalian carbohydrate-binding proteins. Biochim. Biophys. Acta 1999, 1473, 172-185. [CrossRef]

19. Cooper, D.N.; Barondes, S.H. Evidence for export of a muscle lectin from cytosol to extracellular matrix and for a novel secretory mechanism. J. Cell Biol. 1990, 110, 1681-1691. [CrossRef] [PubMed]

20. Nickel, W. Pathways of unconventional protein secretion. Curr. Opin. Biotechnol. 2010, 21, 621-626. [CrossRef] [PubMed] 
21. Sarkari, P.; Feldbrügge, M.; Schipper, K. The corn smut fungus Ustilago maydis as an alternative expression system for biopharmaceuticals. In Fungal Biology. Gene Expression Systems in Fungi: Advancements and Applications; Schmoll, M., Dattenböck, C., Eds.; Springer Book Series; Springer International Publishing Switzerland: Cham, Switzerland, 2016; pp. 183-200.

22. Feldbrügge, M.; Kellner, R.; Schipper, K. The biotechnological use and potential of plant pathogenic smut fungi. Appl. Microbiol. Biotechnol. 2013, 97, 3253-3265. [CrossRef] [PubMed]

23. Koepke, J.; Kaffarnik, F.; Haag, C.; Zarnack, K.; Luscombe, N.M.; König, J.; Ule, J.; Kellner, R.; Begerow, D.; Feldbrügge, M. The RNA-binding protein RRM4 is essential for efficient secretion of endochitinase Cts1. Mol. Cell. Proteom. 2011, 10. [CrossRef] [PubMed]

24. Stock, J.; Sarkari, P.; Kreibich, S.; Brefort, T.; Feldbrügge, M.; Schipper, K. Applying unconventional secretion of the endochitinase Cts1 to export heterologous proteins in Ustilago maydis. J. Biotechnol. 2012, 161, 80-91. [CrossRef] [PubMed]

25. Sarkari, P.; Reindl, M.; Stock, J.; Müller, O.; Kahmann, R.; Feldbrügge, M.; Schipper, K. Improved expression of single-chain antibodies in Ustilago maydis. J. Biotechnol. 2014, 191, 165-175. [CrossRef] [PubMed]

26. Langner, T.; Göhre, V. Fungal chitinases: Function, regulation, and potential roles in plant/pathogen interactions. Curr. Genet. 2016, 62, 243-254. [CrossRef] [PubMed]

27. Langner, T.; Özturk, M.; Hartmann, S.; Cord-Landwehr, S.; Moerschbacher, B.; Walton, J.D.; Göhre, V. Chitinases are essential for cell separation in Ustilago maydis. Eukaryot. Cell 2015, 14, 846-857. [CrossRef] [PubMed]

28. Stock, J.; Terfrüchte, M.; Schipper, K. A reporter system to study unconventional secretion of proteins avoiding $N$-glycosylation in Ustilago maydis. In Unconventional Protein Secretion: Methods and Protocols; Pompa, A., de Marchis, F., Eds.; Springer Protocols; Springer: New York, NY, USA, 2016; Volume 1459, pp. 149-160.

29. Muyldermans, S. Single domain camel antibodies: Current status. J. Biotechnol. 2001, 74, 277-302. [CrossRef]

30. Joosten, V.; Lokman, C.; van den Hondel, C.A.; Punt, P.J. The production of antibody fragments and antibody fusion proteins by yeasts and filamentous fungi. Microb. Cell Factories 2003, 2, 1. [CrossRef]

31. Desmyter, A.; Spinelli, S.; Roussel, A.; Cambillau, C. Camelid nanobodies: Killing two birds with one stone. Curr. Opin. Struct. Biol. 2015, 32, 1-8. [CrossRef] [PubMed]

32. Rothbauer, U.; Zolghadr, K.; Tillib, S.; Nowak, D.; Schermelleh, L.; Gahl, A.; Backmann, N.; Conrath, K.; Muyldermans, S.; Cardoso, M.C.; et al. Targeting and tracing antigens in live cells with fluorescent nanobodies. Nat. Methods 2006, 3, 887-889. [CrossRef] [PubMed]

33. Zarnack, K.; Maurer, S.; Kaffarnik, F.; Ladendorf, O.; Brachmann, A.; Kämper, J.; Feldbrügge, M. Tetracycline-regulated gene expression in the pathogen Ustilago maydis. Fungal Genet. Biol. 2006, 43, 727-738. [CrossRef] [PubMed]

34. Fedorov, A.; Saxonov, S.; Gilbert, W. Regularities of context-dependent codon bias in eukaryotic genes. Nucleic Acids Res. 2002, 30, 1192-1197. [CrossRef] [PubMed]

35. Kämper, J.; Kahmann, R.; Bölker, M.; Ma, L.J.; Brefort, T.; Saville, B.J.; Banuett, F.; Kronstad, J.W.; Gold, S.E.; Müller, O.; et al. Insights from the genome of the biotrophic fungal plant pathogen Ustilago maydis. Nature 2006, 444, 97-101. [CrossRef] [PubMed]

36. Doehlemann, G.; Reissmann, S.; Assmann, D.; Fleckenstein, M.; Kahmann, R. Two linked genes encoding a secreted effector and a membrane protein are essential for Ustilago maydis-induced tumour formation. Mol. Microbiol. 2011, 81, 751-766. [CrossRef] [PubMed]

37. Funkhouser, J.D.; Aronson, N.N., Jr. Chitinase family GH18: Evolutionary insights from the genomic history of a diverse protein family. BMC Evolut. Biol. 2007, 7, 96. [CrossRef] [PubMed]

38. Jankowski, S. Charakterisierung der Unkonventionell Sekretierten Endochitinase Cts1 in Ustilago maydis. Master's Thesis, Heinrich Heine University Düsseldorf, Düsseldorf, Germany, 2013.

39. Mukherjee, J.; Tremblay, J.M.; Leysath, C.E.; Ofori, K.; Baldwin, K.; Feng, X.; Bedenice, D.; Webb, R.P.; Wright, P.M.; Smith, L.A.; et al. A novel strategy for development of recombinant antitoxin therapeutics tested in a mouse botulism model. PLOS ONE 2012, 7, e29941. [CrossRef] [PubMed]

40. Rothbauer, U.; Zolghadr, K.; Muyldermans, S.; Schepers, A.; Cardoso, M.C.; Leonhardt, H. A versatile nanotrap for biochemical and functional studies with fluorescent fusion proteins. Mol. Cell Proteom. 2008, 7, 282-289. [CrossRef] [PubMed] 
41. Arnon, S.S.; Schechter, R.; Maslanka, S.E.; Jewell, N.P.; Hatheway, C.L. Human botulism immune globulin for the treatment of infant botulism. N. Engl. J. Med. 2006, 354, 462-471. [CrossRef] [PubMed]

42. Centers for Disease Control. Investigational heptavalent botulinum antitoxin (HBAT) to replace licensed botulinum antitoxin AB and investigational botulinum antitoxin E. Morb. Mortal. Wkly. Rep. 2010, 59, 299.

43. Ardekani, L.S.; Gargari, S.L.; Rasooli, I.; Bazl, M.R.; Mohammadi, M.; Ebrahimizadeh, W.; Bakherad, H.; Zare, H. A novel nanobody against urease activity of Helicobacter pylori. Int. J. Infect. Dis. 2013, 17, 723-728. [CrossRef] [PubMed]

44. Katoh, Y.; Nozaki, S.; Hartanto, D.; Miyano, R.; Nakayama, K. Architectures of multisubunit complexes revealed by a visible immunoprecipitation assay using fluorescent fusion proteins. J. Cell Sci. 2015, 128, 2351-2362. [CrossRef] [PubMed]

45. Wang, Y.; Fan, Z.; Shao, L.; Kong, X.; Hou, X.; Tian, D.; Sun, Y.; Xiao, Y.; Yu, L. Nanobody-derived nanobiotechnology tool kits for diverse biomedical and biotechnology applications. Int. J. Nanomed. 2016, 11, 3287-3303. [CrossRef] [PubMed]

46. De Meyer, T.; Muyldermans, S.; Depicker, A. Nanobody-based products as research and diagnostic tools. Trends Biotechnol. 2014, 32, 263-270. [CrossRef] [PubMed]

47. Muyldermans, S. Nanobodies: Natural single-domain antibodies. Annu. Rev. Biochem. 2013, 82, $775-797$. [CrossRef] [PubMed]

48. Frenken, L.G.; van der Linden, R.H.; Hermans, P.W.; Bos, J.W.; Ruuls, R.C.; de Geus, B.; Verrips, C.T. Isolation of antigen specific llama VHH antibody fragments and their high level secretion by Saccharomyces cerevisiae. J. Biotechnol. 2000, 78, 11-21. [CrossRef]

49. Okazaki, F.; Aoki, J.; Tabuchi, S.; Tanaka, T.; Ogino, C.; Kondo, A. Efficient heterologous expression and secretion in Aspergillus oryzae of a llama variable heavy-chain antibody fragment $\mathrm{V}(\mathrm{HH})$ against EGFR. Appl. Microbiol. Biotechnol. 2012, 96, 81-88. [CrossRef] [PubMed]

50. Rodriguez, M.; Lustigman, S.; Montero, E.; Oksov, Y.; Lobo, C.A. PfRH5: A novel reticulocyte-binding family homolog of Plasmodium falciparum that binds to the erythrocyte, and an investigation of its receptor. PLoS ONE 2008, 3, e3300. [CrossRef]

51. Douglas, A.D.; Baldeviano, G.C.; Lucas, C.M.; Lugo-Roman, L.A.; Crosnier, C.; Bartholdson, S.J.; Diouf, A.; Miura, K.; Lambert, L.E.; Ventocilla, J.A.; et al. A PfRH5-based vaccine is efficacious against heterologous strain blood-stage Plasmodium falciparum infection in aotus monkeys. Cell Host Microbe 2015, 17, 130-139. [CrossRef] [PubMed]

52. Bustamante, L.Y.; Bartholdson, S.J.; Crosnier, C.; Campos, M.G.; Wanaguru, M.; Nguon, C.; Kwiatkowski, D.P.; Wright, G.J.; Rayner, J.C. A full-length recombinant Plasmodium falciparum PfRH5 protein induces inhibitory antibodies that are effective across common PfRH5 genetic variants. Vaccine 2013, 31, 373-379. [CrossRef] [PubMed]

53. Hjerrild, K.A.; Jin, J.; Wright, K.E.; Brown, R.E.; Marshall, J.M.; Labbe, G.M.; Silk, S.E.; Cherry, C.J.; Clemmensen, S.B.; Jorgensen, T.; et al. Production of full-length soluble Plasmodium falciparum RH5 protein vaccine using a Drosophila melanogaster Schneider 2 stable cell line system. Sci. Rep. 2016, 6, e30357. [CrossRef] [PubMed]

54. Baum, J.; Chen, L.; Healer, J.; Lopaticki, S.; Boyle, M.; Triglia, T.; Ehlgen, F.; Ralph, S.A.; Beeson, J.G.; Cowman, A.F. Reticulocyte-binding protein homologue 5-An essential adhesin involved in invasion of human erythrocytes by Plasmodium falciparum. Int. J. Parasitol. 2009, 39, 371-380. [CrossRef] [PubMed]

55. Ord, R.L.; Rodriguez, M.; Yamasaki, T.; Takeo, S.; Tsuboi, T.; Lobo, C.A. Targeting sialic acid dependent and independent pathways of invasion in Plasmodium falciparum. PLoS ONE 2012, 7, e30251. [CrossRef] [PubMed]

56. Crosnier, C.; Bustamante, L.Y.; Bartholdson, S.J.; Bei, A.K.; Theron, M.; Uchikawa, M.; Mboup, S.; Ndir, O.; Kwiatkowski, D.P.; Duraisingh, M.T.; et al. Basigin is a receptor essential for erythrocyte invasion by Plasmodium falciparum. Nature 2011, 480, 534-537. [CrossRef] [PubMed]

57. Reddy, K.S.; Pandey, A.K.; Singh, H.; Sahar, T.; Emmanuel, A.; Chitnis, C.E.; Chauhan, V.S.; Gaur, D. Bacterially expressed full-length recombinant Plasmodium falciparum RH5 protein binds erythrocytes and elicits potent strain-transcending parasite-neutralizing antibodies. Infect. Immun. 2014, 82, 152-164. [CrossRef] [PubMed] 
58. Clare, J.J.; Rayment, F.B.; Ballantine, S.P.; Sreekrishna, K.; Romanos, M.A. High-level expression of tetanus toxin fragment $\mathrm{C}$ in Pichia pastoris strains containing multiple tandem integrations of the gene. Nat. Biotechnol. 1991, 9, 455-460. [CrossRef]

59. Wang, G.; Xia, Y.; Gu, Z.; Zhang, H.; Chen, Y.Q.; Chen, H.; Ai, L.; Chen, W. A new potential secretion pathway for recombinant proteins in Bacillus subtilis. Microb. Cell Factories 2015, 14, 179. [CrossRef] [PubMed]

60. Chen, J.; Zhao, L.; Fu, G.; Zhou, W.; Sun, Y.; Zheng, P.; Sun, J.; Zhang, D. A novel strategy for protein production using non-classical secretion pathway in Bacillus subtilis. Microb. Cell Factories 2016, 15, 69. [CrossRef] [PubMed]

61. Holliday, R. Ustilago maydis. In Handbook of Genetics; Plenum Press: New York, NY, USA, 1974; Volume 1, pp. 575-595.

62. Bösch, K.; Frantzeskakis, L.; Vranes, M.; Kämper, J.; Schipper, K.; Göhre, V. Genetic manipulation of the plant pathogen Ustilago maydis to study fungal biology and plant microbe interactions. J. Vis. Exp. 2016. [CrossRef] [PubMed]

63. Brachmann, A.; König, J.; Julius, C.; Feldbrügge, M. A reverse genetic approach for generating gene replacement mutants in Ustilago maydis. Mol. Genet. Genom. 2004, 272, 216-226. [CrossRef]

64. Loubradou, G.; Brachmann, A.; Feldbrügge, M.; Kahmann, R. A homologue of the transcriptional repressor Ssn6p antagonizes cAMP signalling in Ustilago maydis. Mol. Microbiol. 2001, 40, 719-730. [CrossRef] [PubMed]

65. Brachmann, A.; Weinzierl, G.; Kämper, J.; Kahmann, R. Identification of genes in the bW/bE regulatory cascade in Ustilago maydis. Mol. Microbiol. 2001, 42, 1047-1063. [CrossRef] [PubMed]

66. Laemmli, U.K. Cleavage of structural proteins during the assembly of the head of bacteriophage T4. Nature 1970, 227, 680-685. [CrossRef] [PubMed]

(C) 2017 by the authors. Licensee MDPI, Basel, Switzerland. This article is an open access article distributed under the terms and conditions of the Creative Commons Attribution (CC BY) license (http:/ / creativecommons.org/licenses/by/4.0/). 